\title{
Türk Vergi Yargısında Re’sen Araştırma İlkesinin Sınırları
}

\author{
Ramazan ARMAĞAN*, Ayşe ARMAĞAN**
}

ÖZ

Yarg1 organlarınca, yargılamanın sağlıklı biçimde yürütülüp sonuçlandırılabilmesi için davaya konu uyuşmazlığa ait ispat araçlarının, davanın taraflarınca yargılama makamına sunulması gerekmektedir. Bu süreçte hâkim gerekli gördüğü hallerde tarafların sunduğu davaya ait bilgi ve belgeler yanında yargılamanın ve kurulacak hükmün isabetli olabilmesi için re'sen araştırma ilkesinden yararlanabilmektedir. Hukuk sistemimizdeki bu ilke ile hâkimlere, baktığı davaya ilişkin doğru, özgür, sağlıklı kararlar vermesini sağlayacak geniş yetki ve görevler verilse de bu yetkiler sınırsız değildir. Özellikle hukuka uygunluk, yerindelik denetimi yapılamaması, ispat, devletin güvenliği veya yüksek menfaatlerine ilişkin sınırlar, mükellef hakları, vergi mahremiyeti vb. konular hâkimin yargılama sırasında doğrudan olduğu kadar dolaylı sınırlarının varlığını da ortaya koymaktadır.

Anahtar Kelimeler: Vergi yargısı, Re'sen araştırma ilkesi, Vergi davası, Yargılama ilkeleri

JEL Sinıflandırması: K34, K30, K41

\section{The Limits of the Principle of Ex Officio Examination in the Turkish Tax Judiciary}

\begin{abstract}
By the judicial organs, the means of proof of the dispute subject to the case must be submitted to the judicial authority by the parties of the case so that the trial can be conducted and concluded in a healthy manner. In this process, when the judge deems necessary, besides the information and documents of the case presented by the parties, the judge can make use of the principle of ex officio examination in order to make the judgment and the verdict to be established. With this principle in our legal system, the judges, regarding the case they deal with; broad powers and duties are given to enable it to make correct, free and healthy decisions, but these powers are not unlimited. Especially, the issues such as compliance with the law, lack of appropriateness control, proof, limits on the security or best interests of the state, taxpayer rights, tax privacy, etc. reveal the existence of direct as well as indirect limits during the trial of the judge.
\end{abstract}

Keywords: Tax judgment, Principle of ex officio examination, Tax case, Principles of judgment

JEL Classification: K34, K30, K41

Geliş Tarihi / Received: 21.04.2021 Kabul Tarihi / Accepted: 06.06.2021 Doi: 10.17541/optimum.923735

\footnotetext{
* Prof. Dr., Süleyman Demirel Üniversitesi, İ̈BF, Maliye Bölümü, ramazanarmagan @ sdu.edu.tr, ORCID: 0000-00021786-6877

** Dr. Öğr. Üyesi, Manisa Celal Bayar Üniversitesi, Salihli İ̈BF, Maliye Bölümü, ayse.armagan@ @bu.edu.tr, ORCID: 0000-0001-5018-4416
} 


\section{GİRIŞ}

Vergi yargılaması hukukunun anayasal temeli, Anayasanın 2. maddesi olan hukuk devleti ilkesi ve bu ilke gereğince de idarenin yargısal denetimine dayanmaktadır (Öncel, vd., 2008:185). Anayasanın 125. maddesi gereğince hüküm altına alınan idarenin yargısal denetimi, tüm yargılamalarda olduğu gibi vergi yargısında da Anayasanın 142. maddesine göre kurulan mahkemeler tarafından gerçekleştirilmektedir.

Kamu hukukunun alt dallarından biri olan idari yargı içinde kendine özgü uygulamaları ile dikkati çeken vergi yargısında, vergi idaresinin eylem ve işlemleri dava konusunu oluşturmakta ve doğal olarak da davanın taraflardan biri mükellef diğeri de vergi idaresi olmaktadır. Hem idari yargı hem de vergi yargısındaki bu durum; idarenin üstün konumda oluşu, kamu yararının varlığı ve önemi, idarenin sahip olduğu bilgi, belge, diğer kaynak ve imkânların zenginliği vb. alanlarda taraflar arasında eşitsizliği ortaya çıkarabilmektedir. Bu nedenle yargı sürecinde davanın tarafları arasında eşitlik sağlanabilmesi ve yargılamanın isabetli yapılabilmesi amacıyla hâkimlere etkin ve özgür bir şekilde re'sen hareket edebilme imkânının verilmesi gerekliliği ve önemi ortaya çıkmıştır (Zabunoğlu, 1982: 157).

Re'sen araştırma ilkesinin hukuki temeli Anayasaya, kanunlara ve idari düzenlemelere dayanmaktadır. Bu ilkenin ana amaçları; anayasaya, demokrasiye, sosyal adalet ilkesine, eşitlik ilkesine, kanunilik ilkesine uygun vergilendirmeyi gerçekleştirmektir. Hâkimlere, bu amaçları gerçekleştirebilmeleri için hem usule hem de maddi olaya ait hususlarda kendiliğinden inceleme, araştırma, tetkik etme, irdeleme hakk1 vb. geniş yetkiler ve görevler yüklenmiştir. Ancak re'sen araştırma ilkesiyle hâkim; doğru, özgür, sağlıklı kararlar verebilmesine yönelik yetki ve görev ile donatılmış olsa da söz konusu yetkiler sonsuz olmayıp, bazı konu ve şartlarla sınırlandırılmıştır. Bu sınırlar; özellikle devletin güvenliği veya yüksek menfaatlerine ilişkin sınırlar, hâkimin keyfi davranmamasına ilişkin sınırlar, vergi mahkemelerinin yerindelik denetimi yapamamalarına ilişkin sınırlar, takdir yetkisi ve hukuka uygunluk denetimi yönüyle sınırlar, ispat ve vergi mahremiyetine ilişkin sınırlar, Danıştay içtihatları ile oluşan sınırlar ve re'sen araştırma ilkesinin diğer yargılama ilkeleriyle sınırlı oluşu gibi konularda kendini göstermektedir.

$\mathrm{Bu}$ çalışmada vergi davalarının görülmesinde yargı kararlarının isabetliliğini artırmaya yönelik olan re'sen araştırma ilkesi, dolaylı/dolaysız sınırları ile etkileri ve sonuçları üzerine literatür ve yargı kararları dikkate alınarak bir değerlendirmeye yer verilmektedir.

\section{VERGİ YARGILAMASI HUKUKUNUN ILKELERİ VE RE'SEN ARAŞTIRMA İLKESI}

Yargılama ilkeleri; yargılamaya ilişkin kuralları her yönüyle sistematik hale getirerek yargılamaya bir bütün olarak bakmayı sağlayan, kuralların açıklanmasında ve kanunlarda oluşan boşlukların doldurulmasında yararlanılan üst normlardır (Üstün, 2019: 1). 6100 sayılı Hukuk Muhakemeleri Kanunu (HMK)'nun 24-33. maddelerinde yargilamaya egemen olan ilkeler; tasarruf (24. md.), taraflarca getirilme (25. md.), taleple bağl1lı (26. md.), hukuki dinlenilme hakk1 (27. md.), aleniyet (28. md.), dürüst davranma ve doğruyu söyleme yükümlülüğü (29. md.), usûl ekonomisi (30. md.), hâkimin davayı aydınlatma ödevi (31. md.), yargılamanın sevk ve idaresi (32. md.), hukukun uygulanması (33. md.) olarak sayılmıştır.

Yasal dayanaklarını İdari Yargılama Usulü Kanunu (IYUK) ve Vergi Usul Kanunu (VUK)'ndan alan bu ilkeler idari yargı için de geçerlidir. Ayrıca idari yargılama usulünde kendine özgü yapısından kaynaklanan; re'sen araştırma, tasarruf ve yazılılık ilkelerinin de eklendiği görülmektedir. Bu ilkelerin, kamusal özelliği ve kamu yararı unsurunun üstünlüğü nedeniyle ceza yargılaması ile yakınlık göstermektedir (Kumrulu, 1989: 66) Dolayısıyla idari 
yargılama hukukunda kabul gören ilkeler vergi yargısı ile birlikte diğer yargılama hukuklarında da geçerli hale gelen ilkeler konumundadır.

Vergi yargılaması hukuku; kurumlar yönüyle medenî yargılama; ilkeler bakımından ise ceza yargılaması hukukuna yakınlık göstermektedir. Vergi yargılaması hukukuna hâkim ilkeler; hukuk devleti, vergilerin kanuniliği, kamuya yararlılık, yazılılık, re'sen (kendiliğinden) araştırma, delil serbestîsi, delillerin serbestçe değerlendirilmesi, ekonomik yaklaşım, usul ekonomisi (çabukluk ve ucuzluk) ve adil (doğru) yargılanma ilkeleri olarak benimsenmiştir (Karakoç, 2019: 202-213).

Yargılamanın sağlıklı biçimde yürütülüp sonuçlandırılabilmesi bakımından davaya konu uyuşmazlığa ait ispat araçlarının yargılama makamına ulaştırılması zorunludur (Alangoya, 1979: 8). Hâkimin yargılama sonunda bir karar verebilmesi, öncelikle maddi olayların varlı̆̆ıyla bunların tespitine yönelik kanıtların yargı organlarına tevdi edilmesi ve böylece olayın hangi hukuki türe uygunluk gösterdiğinin belirlenmesi ile mümkün olabilecektir (Sunay, 1997: 31-32). Bu konuda yargılama hukuklarında; "taraflarca hazırlama ilkesi" ve "re'sen araştırma ilkesi" şeklinde ilkelerden yararlanılmaktadır.

Taraflarca hazırlama ilkesi, davanın ve savunmanın temelinde yer alan olayların ve bunlara ait kanitların dava taraflarınca mahkemeye verilmesini ifade etmektedir (Kuru, 2016: 239-240). Bu ilkenin yer bulduğu yargılama hukuklarında mahkeme kanıtların toparlanması hususunda yetkisiz konumdadır ve hâkim incelemeyi davanın taraflarınca sunulan kanıtlar üzerinden yapmaktadır.

Re'sen Araştırma İlkesi, davaya konu kanıtların hazırlanmasında, dava taraflarının yanında, mahkemenin de görevli olmasını ifade etmektedir. İdari yargı hâkimi kanıtların araştırılmasında ve yarg1 sürecinde re'sen hareket etme yetkisine sahiptir (Gözübüyük, 2006: 377).

Dava ile ilgili kanıtların oluşturulmasında bu iki ilke birbirinin "alternatifi" (Kuru, vd., 2011: 328) veya "karşıtt" konumda değildir. Ancak medeni yargılama hukukunda "taraflarca hazırlama ilkesi"nin kabulü söz konusu (Alangoya, 1979: 8-9) iken idari ve vergi hukukunda re'sen araştırma ilkesinin geçerli bir ilke olmaktadır (Yavaşlar, 2013: 231). İdari yargılamada, işlemi gerçekleştiren tarafın idare olması nedeniyle işlemle ilgili bilgi ve belgeler idarenin bünyesinde bulunduğu için davacı kanıtları toplama ve bunları mahkemeye sunma yönünde bazı sıkıntılar yaşayabilir. Böylece mahkemeye sunulamayan kanıtların sağlanabilmesi bakımından hâkime re'sen araştırma yetkisinin verilmesi gerekli ve hatta zorunlu bir konu haline gelmektedir.

\subsection{Re'sen Araştırma}

Re'sen kelimesi “kendi başına, kendiliğinden” (Adalet Bakanlığı Hukuk Sözlüğü, 2021), anlamlarıyla ele alınmıştır. Re'sen araştırma ifadesi bazı yazarlara ve IYYUK'a göre şöyle tanımlanmıştır:

Gözübüyük’e (2006) göre; “öğretide, vergi yargllamasında ve genel olarak idari yargılama usulünde, hâkimin kanıtların araştırılmasında ve davanın yürütülmesinde kendiliğinden hareket etme yetkisidir".

Candan'a (2011) göre; “Mahkeme, davaya konu işlemin ya da uyuşmazlığa yol açan idari eylemin hukuka uygunluğunu, tarafların getirdikleri belge ve bilgilerle yetinmeyip bizzat kendisi herhangi bir istek olmaksızın araştırabilir."

IYYUK'un Dosyaların İncelenmesi başlıklı 20. maddesi 1. fikrasında; "Danıştay, bölge idare mahkemeleri ile idare ve vergi mahkemeleri, bakmakta olduklart davalara ait her türlü 
incelemeyi kendiliğinden yapar. Mahkemeler belirlenen süre içinde lüzum gördükleri evrakın gönderilmesini ve her türlü bilgilerin verilmesini taraflardan ve ilgili diğer yerlerden isteyebilirler. Bu husustaki kararları, ilgililerce, süresi içinde yerine getirilmesi mecburidir. Haklı sebeplerin bulunması halinde bu süre, bir defaya mahsus olmak üzere uzatılabilir."

$\mathrm{Bu}$ maddeye göre re'sen araştırma ilkesine yönelik "re'sen araştırma" ifadesi yerine "re'sen inceleme" teriminin kullanıldığ görülmektedir. Bu iki terim arasında bir ayırım söz konusu olup, dava dosyasının incelenmesi ve tamamlanması, kamu düzeni ile ilgili konular ile hâkim tarafindan anlaşılabilecek olan konular, re'sen inceleme kapsamındadır. IYYUK'un 14. maddesinin 3. fikrasında düzenlenen dilekçe hakkındaki ilk inceleme yetkisi, re'sen incelemeye örnek gösterilebilir. Re'sen araştırma ise maddi olayların aydınlatılması ve maddi gerçeğe erişilmesi için dava dosyasında bulunmayan bilgi ve belgelerin hâkim aracılığıyla elde edilmeye çalışılmasıdır. Vergi hâkiminin maddi gerçeği araştırmak için bilirkişi veya uzman kişi tayin etmesi veya keșif yöntemine başvurması, re'sen araştırmaya örnek verilebilir. Ancak maddenin sonraki açılklı getirici ifadeleri ile re'sen incelemenin, re'sen araştırma olarak uygulamada yer bulacağı anlaşılmaktadır (Ergün, 2006: 69).

\subsection{Re'sen Araştırma İlkesi}

İdari davaların kamu yönünün ağır basması nedeniyle yargılama yönteminde re'sen araştırma ilkesinin kabul edilmesi görüşü benimsenmiştir. Re'sen araştırma ilkesi de bazı yazarlara göre şöyle tanımlanmıştır:

Karakoç'a (2019) göre; “yargı organlarının tarafların ileri sürdükleri delillerle bağlı olmaksızın, uyuşmazlık konusu olayın aydınlatılması için kendiliklerinden delil araştırması yapabilmesi, bunlarl yargilamaya sokabilmesidir".

Çağlayan'a (2004) göre; “idari yargı hâkiminin, davanın açılmasından nihai karar verilmesine kadar, davanın sevk ve idaresi, maddi olayın varlı̆̆ının araştırılması, delillerin elde edilmesi; maddi olayın hukuki niteliği, olaya uygulanacak hukuk kuralının tespiti, iddia ve savunmada ortaya konan maddi bulguların, gerçeğe aykırı olup olmadı̆̆ının araştırılması, davanın süresinde açılıp açılmadığının, delillerin takdiri, idarenin sorumluluk esasını tespiti ile tarafların hiç değinmediği olayların tespit edilmesi ile ilgili olarak, tarafların talebiyle bağlı olmaksızın yaptığı tüm araştırmalardır."

Yargı organlarının maddi olayın açığa çıkarılması amacıyla, herhangi bir istek olmadan re'sen duruşma kararı vermeleri de bir re'sen araştırma yöntemidir (Aslan, 2001: 57-58).

IYUK'un 20. maddesindeki “...her çeşit inceleme” ifade, hâkime re'sen araştırma ilkesi gereğince sadece tarafların aykırı düşündükleri konuları değil, uyuştukları konuları da araştırma yetkisi vermektedir (Bayrakl1, 2000: 100).

Re'sen araştırma ilkesine göre yargı organları, davanın taraflarından bağımsız olarak davanın maddi temelini açıklığa kavuşturmak ve bu amaçla da gereken tüm olayları ve kanıtları yargılamaya getirmek ve incelemekle yükümlü kılınmıştır (Özkan, 2005: 28). Dolayısıyla yargılama sürecinde hâkimin, kendisine verilen hak ve görev çerçevesinde re'sen araştırma ilkesinin gereğini yerine getirme sorumluluk ve anlayışı içinde hareket edeceği kabul edilmektedir.

Hukuk sistemimizde kamu hukuku dalı içinde yer alan ve maddi gerçeğe ulaşmayı amaçlayan vergi yargılamasında hâkime, hem usul yönüyle hem de maddi olayla ilgili hususlarda kendiliğinden inceleme ve araştırma yapma yönünde geniş yetki, hak ve görev verilmiştir (Ergün, 2006: 66). Konu hakkında Danıştay 5. Dairesinin E.1989/199, K.1992/983 ve Danıştay 7. Dairesinin E.1992/322, K.1993/4357 kararlarından da re'sen araştırma ilkesinin hâkime yetki, hak ve sorumluluk vermiş olduğu anlaş1lmaktadır (Özkan, 2005: 15). Hâkimin 
bütünüyle etkin rol üstlendiği bu sisteme "tahkik usulü" de denmektedir (Karavelioğlu, 1999: 635).

Re'sen araştırma ilkesi, hem kanıtların sayısal sınırlanmasına engel olmakta, hem de delillerin sınırlı şekilde değerlendirilmesine imkân vermemektedir. $\mathrm{Bu}$ durum, takdiri delil sistemi ve delil serbestîsi ilkesine kaynak olmaktadır (Karakoç, 2019: 204).

İdari yargıda olduğu gibi vergi yargılaması hukukunda da re'sen araştırma ilkesinin kabul edilme nedeni, kamu yararına öncelik verilmesine dayalıdır (Öncel, vd., 2008: 206). Medeni yargılama hukukunda da bu ilkenin, genellikle kamu düzeninin öne çıtı̆̆ 1 uyuşmazlıklarda uygulama alanı bulduğu görülmektedir. Re'sen araştırma ilkesinin geçerli olabileceği davalar, tarafların dava konusu hakkında serbestçe tasarruf etmelerinin imkânsız olduğu uyuşmazlıklardır (Özmumcu, 2014: 146).

IYYUK 20. maddesinde düzenlenen re'sen araştırma ilkesi idari yargılama hukukunda önemli bir yere sahip olmakla birlikte re'sen araştırma ilkesinin uygulama alanı ancak dava açıldıktan sonra söz konusu olmaktadır. Dava açılması sırasında etkili olmayan bu ilke, davanın sonraki aşamalarında geçerli hale gelmektedir (Özkan, 2005: 12).

Dava açıldıktan sonra re'sen araştırma ilkesi ile tanınan geniş yetkiler çerçevesinde hareket edebilen hâkimler, dava açılmadan önce re'sen araştırma ilkesini dayanak alarak kendi inisiyatifiyle harekete geçememektedir (Gözübüyük, 2006: 465). Böylece re'sen araştırma ilkesine göre hâkim, dava süresince tarafların ileri sürdüğ̈ iddia, savunma, bilgi, belge ve dosyalarla sınırlı olmaksızın gerekliliğine inandığ 1 konularda araştırma yapabilir ve ilgililerden bilgi ve belge isteyerek, dosyanın sonuçlandırılabilmesi için usule yönelik tüm işlemleri yerine getirebilir. Hâkim, davanın yönetilmesi, maddi olayların tespit edilmesi, dava taraflarının hiç yer vermediği olayların ve kanıtların elde edilmesi gibi konularda kendiliğinden araştırma yapabilecektir (Özkan, 2005: 12).

Re'sen araştırma ilkesi bir usul kuralı olup, kamusal yarar kapsamında yargılama sürecinin her alanında ve aşamasında geçerlidir. Bu ilkeyle hâkim, vicdanına dayanarak alacağı karar ile kamu düzenini korumaya çalışmalıdır ve bu amacı gerçekleştirmede tarafların iddia ve istekleriyle de sınırlı tutulmamalıdır (Öncel, vd., 2008: 206).

IYYUK'un 20. maddesinde, mahkemenin re'sen araştırma yetkisini kullanarak elde ettiği bilgi ve belgelerin dava taraflarına bildirilmesi veya fikirlerinin alınmasına yönelik bir hüküm yer almamaktadır. Ancak hâkim, elde edilen yeni bilgi ve belgeleri davayı aydınlatma amacıyla dava taraflarının bilgisine sunma yetkisine sahiptir.

Re'sen araştırma ilkesi, HMK'nın 31. maddesinde yer alan hâkimin davayı aydınlatma ödeviyle de yakından ilişkili bir ilkedir. Ancak hâkimin davayı aydınlatma ödevi, taraflarca getirilme ilkesinin geçerli olduğu davalarda yer bulmaktadır. Re'sen araştırma ilkesinin geçerli olduğu davalarda hâkim, taraflarca iddia edilmese dahi olayları ve bunların kanıtlarını da re'sen inceleyebilmektedir. Bu sebeple, re'sen araştırma ilkesinin uygulandığı davalarda, hâkimin taraflara konuyu açıklattırması, sorular sorarak cevap alması veya davaya ait kanıtları göstermelerini istemesi esasen hâkimin aydınlatma ödevinden değil, re'sen araştırma ilkesinin uygulanmasın bir sonucu olmasından kaynaklanmaktadır (Simil, 2015: 1353).

Dava konusunu oluşturan olaylar belirsizse, tereddütlü, çelişkili durumdaysa veya tarafın beyan ve açıklamaları açık değil, eksik ve tutarsızsa hâkim bu belirsizlikleri re'sen araştırma ilkesi gereğince taraflara sorarak açıklattırmalı, bilgi veya belgelerin getirtilmesini istemelidir (Yavaşlar, 2013: 235-236).

Re'sen araştırma ilkesi, yargılamada kamu düzenine ait konularda (görev, yetki, süre gibi) mahkemenin isabetli bir hüküm kurabilmesi ayrıca, idari yarg1 denetiminin "hukuka uygunluk" denetimi görevini yerine getirmesi ve herhangi bir işlem veya fïlin hukuka 
uygunluğunun tespitinin bazen kapsamlı bir araştırma ve incelemeyi gerektirebilmesi bakımından önem kazanan bir ilkedir (Aslan, 2001: 54).

\subsection{Re'sen Araştırma İlkesinin Amaçları ve Nedenleri}

Re'sen araştırma ilkesi öncelikle demokrasi ilkesi ve sosyal devlet ilkesine uygun vergilendirmeyi amaçlarken anayasa ile koruma altına alınan maddi (verginin mali güçle orantılı olması) ve şekli eşitlik ilkesi ile kanunilik ve idarenin kanuniliği ilkelerinin gerçekleşmesine de hizmet etmektedir (Yavaşlar, 2013: 233-234). Bu ilke; dava taraflarından birinin maruz kaldığ 1 haksızlığın giderilmesi yanında, idarenin hukuk devleti olmanın gereklerine uygun hareket etmesini sağlamaktadır (Özkan, 2005: 31).

Davanın tarafları, vergiyi doğuran olayın ortaya çıkışı, içeriği gibi konularda uyuşmazlık yaşamasalar dahi hâkim maddi gerçeğin ortaya çıkarılması amacıyla ekonomik yaklaşım ilkesini gözeten bir anlayışıyla karar verebilir (Akkaya, 2002: 74).

Re'sen araştırma ilkesinde kamu yararı daha ön planda tutulmakla (Öncel, vd., 2008: 206) birlikte ana amaçları kısaca şöyle sıralanabilir (Güneş, 2017: 119-130):

- Anayasaya uygun vergilendirmeyi gerçekleştirmek,

- Eşitlik ilkesine uygun vergilendirmeyi gerçekleştirmek,

- Kanunilik ilkesine uygun vergilendirmeyi gerçekleştirmek,

- İdarenin kanuniliği ilkesine uygun vergilendirmeyi gerçekleştirmek,

- Diğer anayasal ilkelere uygun vergilendirmeyi gerçekleştirmek

Vergi yargılama hukukunda re'sen araştırma ilkesi temelde 4 nedene dayandırılmıştır. Bunlar (Ergün, 2006: 71-72):

-Vergi yargılama hukukunun, kamu hukuku dalı olması nedeniyle kamu hukukunun uygulanması ve kamu düzeninin sağlanması temel amaçtır. Bu amaçla, vergi hâkimine yargılamayı aktif ve etkili olarak yerine getirebilmesi için re'sen araştırma hak ve görevi verilmiştir.

-Vergi yargısı da diğer yargı dalları gibi hukuk devleti olma amacını gerçekleştirmede bir araç konumundadır.

-Vergi yargılama hukukunun amacı maddi gerçeğe ulaşmaktır. Yargılamada maddi gerçeğe ulaşma gayretinde olan bir hâkime bu yetkinin verilmesi gerekli ve hatta zorunludur.

- Vergi uyuşmazlıklarında taraflardan biri olan idare, kişiye göre her zaman daha güçlü konumdadır ve idarenin elinde davanın diğer tarafı olanlara göre daha fazla bilgi ve belgelere sahip olduğu kabul edilir. Böylece yargılamada tarafların eşitliğinin sağlanabilmesi ve hâkimin sağlıklı bir karar verilebilmesi açısından re'sen araştırma yetkisi tanınması gerekir.

\subsection{Re'sen Araştırma Yetkisine Sahip Olanlar}

IYUK 20. maddesinde Danıştay, bölge idare mahkemeleri ile idare ve vergi mahkemelerine re'sen araştırma yetkisinin verildiği belirtilmiştir.

Bölge idare mahkemeleriyle, idare ve vergi mahkemelerinde "savcllı" müessesesi bulunmadığından (Gözübüyük, 2006: 83) re'sen araştırma yetkisi, vergi mahkemelerinde kurul 
halindeki yargılamalarda mahkeme başkanlarınca, tek hâkimle yapılan yargılamalarda ise ilgili hâkimlerce kullanılmaktadır (Özkan, 2005: 29).

Re'sen araştırma yetkisi; 2014 yılına kadar esasen ilk derece mahkemelerine verilmiş ve IYYUK'un 20. maddesinde re'sen araştırma yapabilecek mahkemeler arasında Bölge İdare Mahkemeleri sayılmamıştır. Ancak 2014 yılında 6545 sayılı Kanunla yapılan değişiklik gereğince bölge idare mahkemelerinin de dosya incelemesinde her çeşit incelemeyi kendiliklerinden yapabilmesi amaciyla 06.01.1982 tarihli ve 2577 sayll IYUK'un 20. maddesinin 1. fikrasının birinci cümlesinde yeni madde ihdası 17. madde olarak eklenmiştir.

İdari yargılama usulünde dava dosyası hakkında ilk incelemenin kimler tarafindan ve nasıl yapılacağı konusu İYUK 14. ve 15. maddelerinde açıklanmıştır. Buna göre vergi hâkimi, re'sen araştırma yetkisini davanın başından sonuna kadar tüm aşamalarında kullanma hakkına sahiptir. Dava dilekçesi, karşı tarafa tebliğ edilmeden dahi IYYUK 14. maddesinin 3. fikrası gereğince vergi hâkimi, dilekçeler hakkında ilk incelemeyi yapmakla görevlendirilmiştir. Aynı madde gereğince; Danıştay'da daire başkanının görevlendireceği bir tetkik hâkimi, idare ve vergi mahkemelerinde ise mahkeme başkanı veya görevlendireceği bir üye dosya üzerindeki takdir yetkisini; görev ve yetki, ehliyet ve süre, husumet yönüyle ilk inceleme aşamasında ve re'sen araştırma ilkesi doğrultusunda kullanmakta ve incelemektedir (Oğurlu, 1998: 119-133).

Danıştay, temyiz amacıyla baktığı davalarda re'sen inceleme yetkisine sahip değildir (Karakoç, 2019: 207). Ancak Danıştay Kanunu'nun 61. maddesinin 1. fikrasına göre; "Savcılar, ilk derece mahkemesi sıfatıyla Danıştayda görülen dava dosyalarından kendilerine havale olunanları Başsavcı adına incelerler ve esas hakkındaki düşüncelerini, bir ay içinde gerekçeli ve yazıll olarak verirler". Maddenin 2. fikrasına göre de; "Savcllar, ilgili yerlerden Danıştay Başkanlığ aracılığ ile her türlü bilgileri isteyebilecekleri gibi işlem dosyalarını da getirtebilirler." ifadeleriyle Danıştay savcılarının ilk derece mahkemesi olarak re'sen araştırmada yetkili ve görevli olduğu ifade edilmiştir.

\section{TÜRK VERGİ YARGILAMA HUKUKUNDA RE'SEN ARASTIRMA ILKESİ}

Anayasa'nın 73. maddesi vergi ödevini; "Herkes, kamu giderlerini karşılamak üzere, mali gücüne göre, vergi ödemekle yükümlüdür" ifadesiyle açılamış ve verginin mali güçle orantılı olması ilkesini esas almıştır. Böylece mali gücü eşit olanların eşit, farklı olanların da farklı durumlara uyumlu şekilde vergilendirilmesi gerekecektir (Yavaşlar, 2012: 398). Bu görev anayasal kurallar çerçevesinde şekli ve maddi eşitlik emri ile vergi idaresinin re'sen araştırma ilkesiyle vergilendirmeyi hayata geçirmesiyle mümkün olabilecektir (Güneş, 2017: 121).

Vergileme işlemlerinin gerçekleştirilmesi sonucu ortaya çıkan vergi uyuşmazlıklarının yargı aşamasında çözümlenmesiyle ilgili düzenlemeler; 2576 sayılı "Bölge İdare Mahkemeleri, İdare Mahkemeleri ve Vergi Mahkemelerinin Kuruluşu ve Görevleri Hakkında Kanun" ile 2577 sayılı “İdari Yargılama Usulü Kanunu”nda yer almaktadır (Karakoç, 2019: 40-41).

Vergisel işlemler, Anayasa'da belirtildiği gibi devletin egemenlik yetkisine dayanarak kamu hizmetlerini yerine getirmek amacıyla yapılmaktadır. Bu nedenle özel hukuktan ayrılan vergi hukukunda görevli hâkimin yetkisi, idari davalara bakan hâkimin yetkisiyle aynı olmaktadır (Karakoç, 2019: 33). Vergi yargılama hukukunda re'sen araştırma ilkesinin yasal temeli, vergi yargısının idari yargı içinde yer alması nedeniyle 2577 sayılı IYUK'tur. IYYUK dışında 2575 sayılı Danıştay Kanunu ile 2576 sayılı Kanunda bu ilkeye yönelik hükümler bulunmamaktadır (Oktar, 2010: 383). Dolayısıyla vergi yargısında re'sen araştırma ilkesinin geçerli olduğu sonucuna yorumla ulaşılmaktadır (Öncel, vd., 2008: 207).

Vergi uyuşmazlıklarının çözümünde uygulanan bazı usul kurallarının IYUK'ta yer alması nedeniyle VUK, idari yargılama usulü hukukunun kaynaklarından biridir (Kalabalık, 
2013: 40). IYYUK 31. maddesinin 2. fikrasinda "bu kanun ve yukarıdaki fikra uyarınca Hukuk Usulü Muhakemeleri Kanununa atıfta bulunan haller sakl kalmak üzere, vergi uyuşmazlıklarının çözümünde Vergi Usul Kanununun ilgili hükümleri uygulanır." ifadesiyle vergi uyuşmazlıklarıyla ilgili özel olarak bir atıf yapılmaktadır. Buna göre, idari yargının görev alanındaki uyuşmazlıkların çözümünde IYUK'da hüküm bulunmayan ve bu kanunla atıf yapılan durumlarda HMK'nın hükümleri uygulanır. Örneğin IYYUK 31. maddesine göre IYYUK' da hüküm bulunmaması durumunda hâkimin davaya bakmaktan yasaklanması ve reddi, ehliyet, üçüncü kişilerin davaya katılması, davanın ihbarı gibi işlemlerde HMK hükümleri uygulanacaktır. IYUK ile HMK'ya atıfta bulunulan durumlar saklı kalmak üzere vergi uyuşmazlıklarının çözümünde VUK'un hükümleri uygulanır (Odyakmaz, vd., 2012: 251). İYUK, HMK ve VUK hükümleri, vergi yargılama hukukunda re'sen araştırma ilkesi bakımından uygulanabilir nitelikte olmaktadır.

Re'sen araştırma ilkesinin vergi hukukundaki kaynağı, 213 sayılı VUK'un 3. maddesidir. Maddenin "İspat" başlıklı " $B$ " bendinde; "vergilendirmede vergiyi doğuran olay ve bu olaya ilişkin muamelelerin gerçek mahiyeti esastır" denilerek, vergilemede varlığı söz konusu olan olayın gerçek içeriğinin belirleyiciliği vurgulanmıştır. Vergilendirme işlemine ait olmakla birlikte davaya konu işlemde asıl maddi olayın tespit edilmesi ve bu amaçla da vergi hâkiminin re'sen araştırma yönünde hareket etmesi gerekmektedir (Güneş, 2017: 167).

VUK 3. maddesinde; "Vergi muamelelerinin gerçek mahiyeti esastır. Vergiyi doğuran olay ve bu olaya ilişkin muamelelerin gerçek mahiyeti yemin hariç her türlü delille ispatlanabilir." ayrıca 19. maddesindeki; "Vergi alacağı, vergi kanunlarının vergiyi bağladıkları olayın vukuu veya hukuki durumun tekemmülü ile doğar." ifadeleriyle vergilendirme işleminin, vergiyi doğuran olayın meydana gelmesiyle gerçekleşeceği belirtilmektedir. Vergiyi doğuran olayla ilgili belgelerin ve yarg1 organlarına verilecek kanıtların, vergi yargisında, idarenin yanı sıra vergi ödevlisinde de bulunması mümkündür (Özkan, 2005: 28-29).

Re'sen araştırma ilkesi esasen "iptal davaları" konularında uygulanmaktadır. Ancak IYUK'da davalar arasında ayrım yapılmadığı (Kumrulu, 1989: 86-271) ve genellikle vergi davalarının tam yargı davası sayılması sebebiyle (Kalabalık, 2013: 210) re'sen araştırma ilkesi bu davalar için de uygulanabilmektedir.

Re'sen araştırma ilkesinin uygulama alanı bulduğu yargılama usullerinde taraflar dava malzemesinin toparlanması hususunda bertaraf edilmemekte aksine kendilerine görevler yüklenmektedir. Çünkü tarafların yardımları olmadan uyuşmazlık konusu olayların açığa çıkarılması çok zordur, hatta mümkün de olmayabilir (Karakoç, 2019: 205). Re'sen araştırma ilkesinde, hem taraflar hem de hâkim, ileri sürülen olay ve delillerle bağlı olmayacak ve yargılama sırasında aktif rol alacaklardır. Davanın açılmasıyla birlikte davanın taraflarına, yargılama sürecinde iddia ve delillerini ileri sürme hakları verilmekle birlikte yargıya yardımc1 olma ve katkıda bulunma ödevleri de yüklenmiştir (Pekcanıtez, vd., 2007: 311-312).

Dava taraflarının yargıya yardımcı olma yönündeki bu ödevleri, mahkemenin re'sen araştırma yükümlülüğünü ortadan kaldırmamaktadır. Mahkeme, tarafların bu yükümlülüklerini yerine getirmemeleri halinde de diğer tüm unsurları dikkate alarak uyuşmazlık konusu olayın nihai değerlendirmesinde göz önünde bulundurmak ve davada taleple sınırlı olarak karar vermek zorundadır. Davacının yardımcı olma yükümlülüğünü yerine getirmemesi halinde mahkemenin, davayı aydınlatma ödevinin sınırlandırıldığı sonucunun çıkarılmaması gerekir. Re'sen araştırma ilkesi, mahkemelerin davaya konu olayları ve bunların delillerini bizzat araştırması değil, bunların doğruluğu konusunda sadece kendisinin sorumlu tutulması anlamına gelmektedir (Karakoç, 2019: 205-206). 


\section{TÜRK VERGİ YARGISINDA RE'SEN ARAŞTIRMA ILKESINIIN SINIRLARI}

Re'sen araştırma ilkesinin sınırlarını belirleyebilmek konusunda öncelikle idarenin yargısal denetiminin Anayasal sınırlarını görmek gerekecektir. Türkiye'de idarenin yargısal denetiminin sınırlarının Anayasa'nın 125. maddesinde; idarenin yargısal denetiminin hukuka uygunluk denetimi ile sinırlı olmas1, yerindelik denetimi yapılamaması, takdir yetkisini kaldıracak nitelikte yargı kararı verilememesi ve nihayetinde yürütme görevinin kanunlarda gösterilen şekil, usul ve esaslara uygun olarak yerine getirilmesini sınırlayacak şekilde yargı kararı verilememesi şeklinde çizildiği görülmektedir (Kalabalık, 2013: 28-30).

Re'sen araştırma ilkesi Anayasa'nın 125. maddesinde yer aldığı üzere, esasen idari yargının görev alanının da çizildiği "idarenin her türlü eylem ve işlemler..."in incelenmesi esnasında yerine getirilebilecektir. Ancak hâkime verilen re'sen araştırma hak ve görevinin kapsamı çok geniş tutulmakla birlikte sonsuz hak ve yetki tanınmamaktadır (Güneş, 2017: 5152).

Re'sen araştırma ilkesine yönelik kurallar, ilkenin sınırlarını çizmekte ve uygulama alanının tespitini de gerçekleştirmektedir. Re'sen araştırma ilkesini sınırlayıcı özellikteki asıl hükümler IYYUK 2., 16., 20., ve 21. maddeleri ile VUK 3. maddesinde yer almaktadır. Bu ilkenin mahkemeler tarafından uygulanması esnasında Danıştay tarafından içtihatlarla oluşturulmuş sınırlamaları da bulunmaktadır. Bu doğrudan sınırlarla birlikte dolaylı sınırlar da söz konusudur.

\section{1. İdari Yargılama Usulü Kanunu Kapsamında Sınırlar}

\subsubsection{Hukuka Uygunluk Denetimi Yönüyle Stnırlart}

İdarenin işlem ve eylemlerinde hukuka uygun davranması esastır ve yapmış oldukları eylem ve işlemler nedeniyle denetime tabi tutulmaktadır. Bu denetimin iki amacı bulunmaktadır. Bunlardan birincisi, söz konusu işlem ve eylemlerin hukuka aykırılığını önlemek (hukuksal denetim); diğeri de kamu yararının en rasyonel şekilde gerçekleşmesini (yerindelik denetimi) sağlamaktır (Odyakmaz, vd., 2012: 1).

Hukuka uygunluk denetimi; idarenin işlem ve eylemlerinin yürürlükteki ilgili mevzuata, yargı içtihatlarına ve devamlı hale gelen idari uygulamalara şekil ve esas yönden aykırı olup olmadığının araştırılmasıdır (Çağlayan, 2011: 211-212). Hukuka uygunluk denetimi ile maddi olaylar ve olgular yorumlanmakta ve nitelikleri ortaya çıarılmaktadır (Yenice ve Esin, 128). Mahkemeler, idarenin hukuk kurallarının izin verdiği ölçüde görev ve yetkilerini yerine getirip getirmediklerini araştırırlar ve eğer hukuka aykırılık varsa mahkemelerce idarenin işlemi iptal edilir (Kalabalık, 2013: 28).

İdari yargiya ait yetki, idarenin eylem ve işlemlerinin hukuka uygunluk denetimi ile sınırlı bulunmaktadır. İdari yargı organları idarenin gerçekleştirdiği işlemlerin sadece hukuka uygunluğunu denetleyebilirler (Odyakmaz, vd., 2012: 38).

Hukuka uygunluk denetimi ilkesi, Anayasa'nın 125. maddesinin 4. fikrasında; "Yargl yetkisi, idarî eylem ve işlemlerin hukuka uygunluğunun denetimi ile sinırlı olup, hiçbir surette yerindelik denetimi şeklinde kullanılamaz. Yürütme görevinin kanunlarda gösterilen şekil ve esaslara uygun olarak yerine getirilmesini kisitlayacak, idari eylem ve işlem niteliğinde veya takdir yetkisini kaldıracak biçimde yargı kararı verilemez" şekilde ifade edilmiştir.

Re'sen araştırma ilkesiyle ilgili IYUK 20. maddesinde; genel kural ve kapsam belirtildikten sonra, maddenin 3.bendinde doğrudan, diğer 1. ve 2. bentlerinde de dolaylı olarak bu ilkenin sınırlarına değinilmiştir. Öncelikle İYUK 20. maddesinin 1. fikrası ve Danıştay Kanunu'nun 49. maddeleri gereğince, mahkeme tarafindan gerekli görülen tüm bilgi ve belge 
getirilebilecek ve her çeşit inceleme yapılabilecek ancak yargı organlarınca yapılacak bu inceleme, hukuka uygunluk denetimiyle sinırlı kalacaktır.

Yarg1 organlarında olduğu gibi idareye de tanınan yetkiler sınırsız olmayıp, Anayasa ve kanunlarla sınırlandırılmıştır. Verginin kanuniliği ilkesi gereğince; vergi idaresinin vergilendirmenin esasına yönelik düzenleme yapabilmesi mümkün olmamakla birlikte vergisel işlemlerin sağlıklı bir şekilde yürütülmesinde usul açısından tali konularda düzenleme yapabilme imkânı tanınmıştır. Bu kapsamda vergi yargısındaki uyuşmazlıkların barışçıl çözüm yolları ile vergilemeye ilişkin düzenleyici işlemler için idareye kanunlarla takdir yetkisi verilmiş olup, bu yetki süre verme, uzlaşma, tecil gibi konularla sınırlı tutulmuştur. Dolayısıyla bu konuda vergi idaresine yetki veren hükümlerde yer alan esaslar hakkındaki düzenleme yetkisini, uygulamanın usulüne veya ayrıntılara ilişkin esaslar olarak yorumlama zorunluluğu bulunmaktadır (Üstün, 2006: 278). İdarenin takdir yetkisine dayalı gerçekleştirdiği işlemler hukuka uygunluk açısından denetime tabi bir konu olmaktadır. Örneğin Danıştay 5. Dairesinin 20.10.1993 tarihli E.1993/4248, K.1993/3874 say1l1 ${ }^{1}$, Danıştay 9. Dairesinin 11.06.2001 tarihli E.2001/1, K.2001/2124 sayıl1 ${ }^{2}$ kararlarında hukuka uygunluk denetimine yer verilmiştir. IYYUK 2. maddesi, 1. fikrası, a bendi gereğince, idari dava türleri bakımından sınırın “...yetki, şekil, sebep, konu ve maksat yönlerinden biri ile...." ifadesiyle belirlendiği görülmektedir (Gözübüyük, 2006: 20-22).

Kanuni düzenlemeler çerçevesinde idari yargı organlarının yargılama faaliyetlerine 4 sınır getirilmiştir (İbiş, 2013: 94-95):

- İdari yargı denetimi hukukilik ile bağlı olup, yerindelik denetimi yapılamaz,

- Yürütme görevinin yasalarda belirtilen usul ve esaslara göre yerine getirilmesi kisitlanamaz,

- İdarenin takdir yetkisini ortadan kaldıran özellikte karar verilemez,

- İdari eylem ve işlem nitelikli yargı kararı verilemez.

\subsubsection{Yerindelik Denetimi Yapılamamasına İlişkin Sınırlar}

Re'sen araştırma ilkesinin sınırlarından biri, IYYUK 2. maddesi 2. fikrası gereğince vergi mahkemelerinin yerindelik denetimi yapamamaları hükmünden kaynaklanmaktadır. Yerindelik, bir idari işlem veya fiilin gerçekleştirilmesinde, süre, yer, durum ve şartların gereklerine göre idari ihtiyaçlar gereğince hareket etmektir. Başka bir açıdan da takdir yetkisinin, hukuka uygunluk denetimine tabi tutulmayan kısmı olarak ifade edilmektedir (Kalabalık, 2013: 29).

İdarenin, tutum ve davranışlarında yerindeliğinin denetimi, yargı denetiminin dışında kalmaktadır. Yarg1 yerlerinin yerindelik denetimi yapması, yargının idareye müdahalesi, idari politikalarını belirlemesi, yasama, yürütme ve kamuoyuna karşı sorumluluğu olmayan hâkimin, idarenin yerine geçmesi anlamına gelecektir (Gözübüyük, 2006: 18).

IYUK 2. maddesi 2. fikrasındaki; “...Iddari mahkemeler; yerindelik denetimi yapamazlar, yürütme görevinin kanunlarda ve Cumhurbaşkanlı̆̆ kararnamelerinde gösterilen şekil ve esaslara uygun olarak yerine getirilmesini kısıtlayacak, idari eylem ve işlem niteliğinde veya idarenin takdir yetkisini kaldıracak biçimde yargı kararı veremezler." ifadesiyle mahkemelerin yerindelik denetimi yapamayacağı ve idarenin yerine geçerek veya idarenin takdir

\footnotetext{
1 "İdarenin davacıyı kız meslek lisesi bulunan bir yere atama yapma konusunda takdir yetkisi bulunduğu, Mahkemece...idarenin takdir yetkisi kaldırılarak davacının ...'a veya istemiyle sınırlı olan yerlere atamasının yapılması sonucunu doğuracak biçimde hüküm tesis edilmesinde isabet görülmediği”"

2 Taşıtlarda LPG'nin yakıt olarak kullanılmasıyla birlikte, LPG'den alınan Akaryakıt Tüketim Vergisi oranının düşük tutulması nedeniyle ortaya vergi kaybının çıkması ve bu durumun giderilmesi amacıyla LPG'li araçlardan MTV'nin fazla alınmasına açılan iptal davası.
} 
yetkisini kaldıracak nitelikli kararlar verememesi hüküm altına alınmak suretiyle re'sen araştırma ilkesinin başka bir sınırı çizilmiştir.

Vergi yargısında hâkimin, re'sen araştırma yaparken, yerindelik denetimi yapacak nitelikte hareket etmemesi ve karar vermemesi gerekmektedir. Örneğin vergi hâkimi, dava konusu olan vergi matrahından farklı bir matrahın ortaya çıkması halinde vergi idaresinin gerçekleştirdiği işlemlerin iptal edilerek hesaplanan yeni matrahın vergilendirme işlemi olarak kabul edilmesi ya da fazladan alınan verginin iadesinin yapılması şeklinde kararlar veremez. Nihai talepte davacı taraf iptal davası ile dava konusu idari işlemin hukuka aykırılığının tespit edilmesini amaçlar ve bunun dışında yargı merciinden iptal edilecek idari tasarruf yerine başka bir işlemin gerçekleştirilmesini isteyemez (Özkan, 2005: 41-42). Danıştay 6. Dairesinin 13.02.1967 tarihli E.1965/3084, K.1967/183³, Danıştay 7. Dairesinin 12.04.1985 tarihli E.84/3570, K.85/10394 (Gözübüyük, 2006: 18-20), Danıştay 7. Dairesinin 30.11.2005 tarihli E.2004/30, K.2005/30025 , Danıştay 7. Dairesinin 28.12.2004 tarihli E.2002/4487, K.2004/36136 sayılı ve daha birçok kararlarından mahkemelerin yerindelik denetimi yapamayacağı anlaşılmaktadır (Candan, 2011: 242). Mahkemeler verdikleri kararlarla idareleri, istedikleri doğrultuda işlem tesis etmeye zorlayamazlar. Aksi takdirde bu durum idarenin yürütme yetkisini ortadan kaldıracaktır (Bayraklı, 2000: 98).

\subsubsection{Takdir Yetkisini Kaldıracak Nitelikli Yargı Kararı Verilememesine İlişkin Sınırlar}

Anayasanın 125. maddesinin 4. fikrası ve IYUK 2. maddesinin 2. fikrası hükümleri gereğince idare mahkemeleri, idareye tanınan takdir yetkisini kaldıracak şekilde yargı kararı veremezler. Ancak vatandaşlar, dairenin keyfi işlem ve uygulamalarına da bırakılamazlar. Bu nedenle takdir yetkisinin denetlenmesi zorunlu bir hal almaktadır (Kalabalık, 2013: 30).

Danıștay'a göre Anayasanın 125. maddesi ve IYUK 2. maddesinde yer alan "idarenin takdir yetkisini kaldıracak biçimde yargı kararı verilemeyeceği" ifadesi, idari işlemler üzerindeki yargısal denetim ile birlikte idarenin takdir yetkisinin kullanılması konusunda bağlı olacağı sınırları da ortaya koymaktadır.

İdarenin gerçekleştireceği işlem, eylem ve faaliyetlerinde hareket alanının ve şeklinin yasalarla belirtildiği durumlarda idare "bağlı yetki" içerisindedir. Ancak faaliyet alanının geniş̧liği nedeniyle kanun koyucu idareye bazı alanlarda "takdir yetkisi" adı verilen karar alma veya seçim yapma serbestisi bırakmıştır. Takdir yetkisi bir seçim serbestisidir (Candan, 2011: 243). Takdir yetkisi, idarenin yasa hükümleriyle nasıl hareket edeceğini açıklamada yetersiz kaldığı durumlarda oluşan tereddütlerin giderilebilmesi ve ortaya çıkan ihtiyaçların karşılanabilmesi amaciyla tanınmış özgürce karar alabilme veya alternatiflerden birini yine özgürce seçebilme yetisidir. Takdir yetkisi özel bir yetki türü olmamakla birlikte idarenin yetki kullanımının değişik şeklidir ve takdir yetkisinin sınırları da önceden yasa hükümleriyle çizilmiştir (Kaya, 2011: 19). Takdir yetkisine sınır getirilmesinin nedeni idarenin bu yetkiyi keyfi veya dayatıcı şekilde kullanımının önüne geçilerek nerede başlayıp nerde bittiğinin belirlenmesindeki belirsizliğin önlenmesi açısından önem arz etmektedir. Buna rağmen takdir

\footnotetext{
3 “davact, her ne kadar okul yeri için daha müsait yerlerin olduğunu iddia etmekte ise de....okul yerini seçme vazifesi komisyona ait olduğundan ve bu şart da yerine getirildiğinde, mezkur iddia yerinde görülmemiştir"

4 "Takdir Komisyonunca takdir edilen bedelin gerçek rayice uygun olup olmadiğının tespiti için vergi mahkemesince bilirkişi tetkikatı yaptırılarak, sonucuna göre karar verilmesi gerekirken, idari mahkemelerin idari eylem ve işlem niteliğinde karar veremeyeceklerinden bahisle tarhiyatın tamamen terkininde isabet görülmemiştir"

5 "Teminatın iadesi için idareye başvuruda bulunularak bu konuda idari işlem tesis ettirilmeksizin, teminatın iadesi istemiyle açılan davada, vergi mahkemesince istek doğrultusunda karar verilmesinin idarenin yerine geçerek yargl kararı verilmesi olduğundan hukuka aykırı bulunduğu”

6 "...idareye mükellefiyet kaydının silinmesi konusunda bir başvuru ve bu başvurunun reddine dair bir işlem olmaksızın mahkemece mükellefiyet kaydının silinmesine karar verilmesinin idari yetkilerin mahkemece kullanılması anlamina geleceği
} 
yetkisinin sınırları hiçbir zaman tam olarak çizilemediği gibi, bu konu her zaman hukukun tartışmalı konuları arasında yer almıştır (Gerçek, 2010: 28).

İdareye verilen bu yetki kapsamında hareket edebileceğini ancak bu yetkiyi hukuk kuralları çerçevesinde kullanacağını yarg1 organının kabul etmesi gerekecektir. Örneğin, yükümlünün hal ve davranışlarından kaçacağı veya mal varlıklarını kaçıracağı beklentisi içinde teminat istenmesi, yükümlünün zor durumda bulunduğu iddiasıyla süre ve taksitlendirme istemesi gibi. Bu iddiaların gerçek olup olmadığına vergi idaresinin takdir yetkisi ile ulaşılabilir. Dolayısıyla idari yargı organlarının idarenin bu takdir yetkisini ortadan kaldıracak şekilde hüküm kurması yasaklanmıştır (Bayraklı, 2000: 98).

İdari davada hâkim, diğer hususlar yanında idarenin takdir yetkisini kullanırken hizmet gereklerine uygun hareket edip etmediğini, kamu yararını gözetip gözetmediğini de denetlemektedir (Candan, 2011: 245).

Re'sen araştırma ilkesi çerçevesinde hâkim, gerek duyduğu bilgilere, vergi idaresinin sınırlı da olsa takdir yetkisini kullanarak gerçekleştirdiği iş ve işlemlerinde ulaşması ve delil ve ispat yönüyle değerlendirmesi sorun oluşturacaktır.

\subsubsection{Sürenin Geçmesinden Sonra Tarafların Verecekleri Savunmalara veya İkinci Dilekçelere Dayanarak Hak İddia Edememelerine İlişkin Sinırlar}

IYYUK 16. maddesinin 4. fikrası ve 21. maddelerinde düzenlenen ve tarafların süre bitiminden sonra verecekleri savunmalara veya ikinci dilekçelere dayanarak hak iddia edememeleri re'sen takdir yetkisinin kullanılmasında sınırlayıcı bir konudur.

IYYUK 16. maddesinin 4. fikrası ve 20. madde hükümleri ve VUK 3. maddesi B fikrasında yer alan "vergilendirmede vergiyi doğuran olay ve bu olaya ilişkin muamelelerin gerçek mahiyeti esastır" hükmü beraber değerlendirildiğinde dava esnasında vergiyi doğuran olayın gerçek içeriğinin belirlenebilmesi ve adil bir hüküm kurulabilmesi için taraflar istekleri doğrultusunda ek bilgi, belge ve iddiaları mahkemeye sunabileceklerdir.

IYUK 16. maddesinin 4. fikrasının vergi yargılama hukukunda söz konusu olmaması gerektiği görüşü varsa da, bu konunun IYUK'ta bulunması, özellikle ispat yükünün idarede olduğu durumlarda 4. fikra ile birlikte 21. maddenin dikkate alınmasını gerektirmektedir. İdarenin eylem ve işlemlerini bir sebebe dayandırarak yapması ve bu sebebi de yargı önünde ispatlayacak ve açıklayabilecek konumda gerçekleştirmesi gerekir. Özellikle işlemi gerçekleştiren idarenin iddia ve savunmaları hazırlamada sahip olduğu kolaylıklar ile bilgi ve belgeleri elinde bulundurduğunda dahi mahkemeye hiç ya da zamanında sunmaması, davanın geciktirilmesiyle iddia ve savunmanın genişletilmesi yasağı uygulama alanı bulabilmektedir. Böylece mahkemelere intikal eden her maddi olayın niteliklerini göz önünde bulundurarak karar vermeleri gerekmektedir. Vergi uyuşmazlıklarının adil ve isabetli şekilde çözümlenmesiyle idari eylem ve işlemlerin hukuka uygunluğunun denetlenmesinin gerçekleştirilebilmesine, mahkemece hüküm kuruluncaya kadar daima yeni hukuki nedenlerin göz önünde bulundurulmasına ve oluşan maddi olayların ileri sürülmesine firsat tanıyacaktır (Özkan, 2005: 39-40). Ancak tanınan bu imkânlar, davanın görülme süresini uzatması ve sonuçta adil yargılanma hakkı kapsamında makul sürede yargılamanın ihlaline neden olabilme riski açısından bu sinırlama önem arz etmektedir.

\subsubsection{Devletin Güvenliği veya Yüksek Menfaatlerine İlişkin Sınırlar}

Devletin güvenliği veya yüksek menfaatlerine ilişkin sınırlar re'sen araştırma ilkesinin IYYUK 20. maddesinde doğrudan belirtildiği en açık sınırıdır. IYYUK 20. maddesi 3. fikrasındaki; "Ancak, istenen bilgi ve belgeler Devletin güvenliğine veya yüksek menfaatlerine veya Devletin güvenliği ve yüksek menfaatleriyle birlikte yabancı devletlere de ilişkin ise, Cumhurbaşkan ya da ilgili Cumhurbaşkanı yardımcısı veya bakan, gerekçesini bildirmek suretiyle, söz konusu bilgi 
ve belgeleri vermeyebilir. Verilmeyen bilgi ve belgelere dayanularak ileri sürülen savunmaya göre karar verilemez." hükmüyle hangi durumlarda mahkemeye bilgi ve belge verilemeyeceği açık şekilde ifade edilmiştir. Mahkemelerce istenen belgelerin, devlet güvenliği ve çıkarları gerekçesi ile yönetimce gönderilmemesi durumunda, hâkim gerek duyduğu belgeler konusunda bilgi isteyebilir. Aksi takdirde Danıştay'ın E.1996/1345, K.1996/2819 sayılı kararında, istenen bilgileri yönetimin vermemesi halinde genel kurallara göre yarg1 yerinin durumunu değerlendirip, eldeki bilgi ve belgelere dayanarak kararını vereceği belirtilmiş̧tir (Gözübüyük, 2006: 484).

IYYUK 20. maddesi 3. fikrasındaki "gizlilik" kavramıyla, Danıştay 5. Dairesi, 06.06.1991 tarihli E.1990/4297, K.1991/1099 sayılı kararıyla, idarede de gizli olan ve yetkili memurlar dışında hiç kimseye gösterilmemesi gereken belge ve dosyaların anlaşılması gerekecektir. İdarenin belge veya dosya üzerine gönderirken "gizlidir" ifadesini veya ek bir yazıyla gizli olduğunu belirtmesi ilgili belgeye veya dosyaya kendiliğinden gizlilik özelliği kazandırmayacaktır. Bu nedenle mahkemenin bu kapsamda ve gerekli gördüğü incelemeyi kendiliğinden yaparak belge veya dosyanın gizli olup olmadığını kendisinin saptaması ve sonucuna göre de usul işlemlerini gerçekleştirmesi kararına varmıştır (Aslan, 2001: 54).

\subsubsection{Dava Dilekçesinde İleri Sürülen İddia ve Taleple Sınırlılı}

Vergi mahkemesi, kanunlarda belirlenen süreler içinde açılan davalarda, kamu düzeni ile ilgili konular saklı kalmak üzere, dava dilekçesinde ileri sürülen iddia ve talepleri dikkate alarak re'sen araştırmayı yapacaktır. Dava açma süresinin bitimi sonrasında davacı iddia ve talebini değiştirememektedir. Bununla beraber, iddia edilen konular kamu düzenine yönelik ise yani yargı organının re'sen değerlendireceği konulardan ise, bunlar davanın tüm aşamalarında ileri sürülebilir ve/veya vergi hâkimi tarafından dikkate alınır (Karakoç, 2019: 99).

Re'sen araştırma ilkesine göre yargı organları, davalar hakkında her türlü araştırmayı re'sen yapacaklar, belirlenen süre içinde gerekli gördükleri evrakın gönderilmesini, her türlü bilgi ve belgenin verilmesini taraflardan ve ilgili diğer yerlerden isteyebileceklerdir. Bu yetki mahkemenin dava konusu yapılmamış bir idari işlemin varlığını ortaya çıkarıp istem olmasa da hukuka uygunluk denetimi yapabileceği anlamına gelmemektedir. Danıştay 6. Dairesinin 21.10.2015 tarihli ve E.2012/2102, K.2015/6224 sayılı bozma kararında ${ }^{7}$ re'sen araştırma ilkesinin yer aldığı ancak kararın istemle bağlılık ilkesiyle uyuşmadığı yönüyle eleştirilmektedir (Özelçi, 2018: 409-417).

\subsection{7. Şekil ve Usul (Yöntem) Kurallarına İlişkin Sinırlılık}

Şekil ve usule ait kurallar, davanın tarafları için güvence oluşturmakla birlikte hem taraflar hem de hâkimler için izlenmesi gereken yolu göstermektedir.

IYYUK 49. maddesi 2. fikrası gereğince; genel olarak usul hükümlerine uyulmamış olması bozma nedeni olarak belirtilmiştir. Ancak 6545 sayılı Kanunla yapılan değişiklikle usul hükümlerinin uygulanması sırasında kararı etkileyebilecek özellikte yanlışlık veya eksiklikler

\footnotetext{
7 “...Belediyesinde taşınmazı olan kişinin taşınmazını kapsayan alanın bölge parkı olarak ilişkilendirilmesine ilişkin 20.08.2003 tarihli ve... nazım imar planı ile... uygulama planının iptal istemleri” ile 17.05.2011 tarihinde açlan davada İdare Mahkemesi; nazım imar planı yönünden “dava açma süresinin geçmesi”, uygulama imar planı yönünden "davacının taşınmazının bulunduğu alanda henüz bir uygulama imar planının bulunmaması" nedeniyle davanın incelenmeksizin reddine 31.10.2011 tarihinde karar vermiştir. Ancak Danıştay 6. Dairesi, 08.06.2015 tarihinde bir ara kararı ile “...söz konusu parseli de kapsayan alanda bölge parkı uygulama imar planının ..16.01.2014 tarihinde belediyece onaylanarak yürürlüğe girdiğini, Idare Mahkemesince uygulama imar planı ile nazım imar planının davacının iddiaları da gözetilmek suretiyle şehircilik ve planlama ilkeleri ile kamu yararına uygun olup olmadiğının incelenmesi suretiyle yeniden karar verilmesi gerekmektedir" gerekçesiyle idare mahkemesinin kararının bozulmasına hükmetmiştir.
} 
meydana geldiği takdirde bozma nedeninin varlı̆̆ bozulabilmesi için, usul yanlışlı̆̆ aranmaktadır. Taraflar, usule yönelik yapılan sakatlığı ileri sürmeseler dahi Danıştay re'sen konuyu inceleyerek, kararı bozabilecektir. Vergi yargılaması usulünde, re'sen araştırma ilkesinin egemen olması nedeniyle, tüm usul kuralları da emredici niteliktedir (Karakoç, 2019: 152).

Yargılamada re'sen araştırma sırasında kanunda yer almayan yöntemlerle inceleme yapılması mümkün olmadığından, duruşmaya ilişkin olarak IYUK'ta belirtilen esaslar dışında duruşma yapılmaksızın taraflardan birinin ya da üçüncü kişilerin çağrılmasıyla bilgisine başvurularak yapılacak re'sen araştırma da kabul görmeyecektir. Danıştay 3. Dairesi, 25.10.1989 tarihli E.89/452, K.89/2340 sayılı kararında da bu konu yer almıştır (İbiş, 2013: 103). Yine örneğin mahkemece bilirkişi atanması hususunda şekil ve usul şartlarına uygun olarak hareket edilmesi gerekecektir.

Anayasanın 141. maddesine göre, "Bütün mahkemelerin her türlü kararlarl gerekçeli olarak yazılır" hükmü gereğince vergi yargısı organlarınca verilecek kararların "gerekçeli karar" olması, davanın taraflarına kararın nedenini ve dayanaklarını açıklaması, yargı denetimini kolaylaştırması ve etkili kılması bakımından gereklidir. Danıştay, bir kararın gerekçesiz şekilde verilmesini veya yeterli gerekçelere dayandırılmamasını usul eksikliği sayarak bozmuştur (Karakoç, 2019: 152). Anayasaya mahkemesinde sonuçlandırılan/derdest vergi uyuşmazlıklarına ilişkin veriler (2018 yılı) incelendiğinde ise mükellef haklarının ihlali içinde gerekçeli karar verilmesi ihlalinin oranı \%15,1 olarak tespit edilmiştir (Tekbaş ve Hayrullahoğlu, 2018: 267).

Danıştay 3. Dairesinin E.1989/1724, K.1990/3422 sayılı kararında da, “....vergi mahkemelerinde yazıl yargllama usulünün uygulanacağı ve incelemenin evrak üzerinden yapılacă̆ı belirtilmiştir. ....Vergi Mahkemesince re'sen araştırma ve inceleme yapılırken ...kanunda gösterilen bir araştırma yapmaksızın yükümlüye tuz satan kişinin "sözlü" olarak ifadesine başvurmasında isabet görülmemistir." (Özkan, 2005: 69) ifadesiyle usul hükümlerine uygun işlem yapılması gerektiği belirtilmiştir.

\subsubsection{Kanuni Sürelerle Sinırlılık}

IYYUK 20. maddesine göre re'sen araştırma ilkesi gereğince hâkim, belirleyecekleri süre içinde dosya ile ilgili ihtiyaç duyulan belgelerin ve her türlü bilgilerin mahkemeye verilmesini taraflardan ya da diğer yerlerden isteyebilir. Mahkemelerin bu yöndeki kararları, tanınan süreler içinde ilgililerce yerine getirilmek zorundadır. Ancak haklı nedenler söz konusu ise mahkemece verilen bu süre bir kez daha uzatılabilir. Taraflardan biri ara kararın gereğini yerine getirmediği takdirde bunun verilecek karar hakkındaki etkisi önceden belirlenir ve ara kararda bu durum ayrıca bildirilir. Böylece IYYK 20. maddesinin 3. fikrasına göre; mahkemeye sunulmayan bilgi ve belgelere dayanarak iddialara ve savunmalara göre karar verilemeyecektir (Gözübüyük, 2006: 483-484). Dolayısıyla hâkim re'sen araştırma ilkesi gereğince dosya hakkındaki hükmünü ilgililere verilen süre içinde mahkemeye sunulan bilgi ve belgeler nezdinde kurabilecektir. Süre geçtikten ve hüküm verildikten sonra bilgi ve belgelerin hüküm ifade etmesi artık diğer yarg1 yolları kullanıldığ 1 takdirde söz konusu olabilecektir.

IYUK 14. maddesi 3. fikrasına ve 15. maddesi 1. fikrasına göre; davaların, kanunlarda belirlenen dava açma süreleri içinde açılması gerekmektedir. Kanunlarda belirlenen süreler içinde açılan davalar için ancak re'sen araştırma ilkesi geçerli olabilecek, taraflarca ileri sürülmese dahi davanın kanuni süreler içerisinde açılıp açılmadığının ilk inceleme sırasında davanın esasına girilmeden re'sen incelemesi yapılacak ve süresinde açılmayan davaların reddi gerçekleşecektir (Karakoç, 2019: 99). 


\subsection{Vergi Usul Kanunu Kapsamında Sinırlar}

\subsubsection{Vergi Usul Kanunu Kapsamında İspata İlişsin Sınırlar}

VUK 3. maddesine ${ }^{8}$ göre yargılama hukukunda geçerli olan ispat, re'sen araştırma ilkesinin VUK'daki sınırını oluşturmaktadır. VUK 3. maddesi B bendinde belirtilen "İspat" konusu re'sen araştırma ilkesinin sınırını vergi davaları açısından ortaya koymaktadır. Hâkim yargilama sürecinde, "Vergiyi doğuran olay ve bu olaya ilişkin muamelelerin gerçek mahiyeti yemin hariç her türlü delille ispatlanabilir." hükmü gereğince yemin hariç diğer her türlü delilleri re'sen araştırma ve değerlendirme yetkisine sahip olacaktır.

Madde hükmünde belirtilen ve hukuk davalarının çözümünde önemli bir yeri olan ${ }^{9}$ "yemin" konusu vergi davaları açısından uygulama alanı bulmamaktadır. Vergi hukukunda yeminin ispat aracı olarak kullanılmasının kanun koyucu tarafından yasaklandığı madde hükmünden anlaşılmaktadır. $\mathrm{Bu}$ nedenle, gerek idare, gerekse mükellef, ispat yükünün kendilerinde olması halinde, iddialarını ispatlamak amacıyla karşı tarafa yemin teklif edemeyecek, yemin teklif etmeleri durumunda ise bu talep hâkim tarafindan kabul görmeyecektir (Görkem, 2008:384). Türk vergi hukukunda geçerli olmayan "yemin" Alman vergi hukukunda geçerli bir ispat aracıdır. Türk VUK hükümlerinin tam aksine, Alman Vergi Usul Kanunu'na göre yeminli ifade alınmasına vergi mahkemesi karar vermektedir ve vergi idaresi de mükellefin iddia ettiği olguların doğruluğunu yemin ile teyit ederek güçlendirmesini isteyebilmektedir (Biyan, 2012: 247). Vergi hâkiminin VUK gereğince "yemin" ispat aracina başvuramaması re'sen araştırma ilkesinin sınırını oluşturacaktır.

Ayrıca madde hükmünde yer alan "vergiyi doğuran olayla ilgisi tabii ve açık bulunmayan şahit ifadesi ispatlama vasıtası olarak kullanılamaz." ifadesi gereğince vergiyi doğuran olayla tabii ve açık ilgisi bulunmayan şahidin ifadesi kabul görmeyecektir. Bu hüküm, şahit dinlenmesi konusunda dosyayı sadece vergiyi doğuran olayla tabii ve açık ilgisi olan şahidin dinlenmesiyle sınırlandıran bir konuma sokmakta ve hâkimin re'sen araştırma yetki ve görevini sınırlandırmaktadır.

İdarenin işlemini yapabilmesi için gerek duyduğu deliller vergi ödevlisinin elindeyse ve vergi ödevlisinin ödevlerini yerine getirmemesi halinde idarenin bu delilleri elde etmesi zorsa, idarenin ispat yükü ortadan kalkmamakta ancak ispat ölçüsü azalmaktadır (Yavaşlar, 2016: 246247). Vergi ödevlisinin ispat yükü altında bırakılmadığı durumlarda vergilendirme işlemlerinin tespiti için "yaklaşık ispat ölçüsü" ile yetinilmesi söz konusu olacaktır. Vergi usulünün, karinelerin doğal etkisi ve re'sen tarhiyat gibi yollarla, bazı istisnai hallerde dolaylı olarak ispat ölçüsünün azalmasına imkân tanıdığı kabul edilmektedir (Güneş, 2017: 182).

Re'sen araştırma ilkesine göre kural olarak ispat yükü vergi idaresine verilmiştir. Bir konunun vergi ödevlisince iddia edilmesi halinde de bu kural değişmemektedir. Ancak, vergi idaresinin ispat ölçüsü azalacak ve idare sadece "iktisadi, ticari ve teknik icaplara uyan veya olayın özelliğine göre normal ve mutad olan” durumu ispatla yetinecektir (Yavaşlar, 2016: 113127). İspat ölçüsünün azalması demek re'sen araştırma ilkesini sınırlandıran ve hâkimin sınırlı bilgi ve belgeyle karar vermesine neden olan bir konu olacaktır.

\footnotetext{
8 “...B) İspat: Vergilendirmede vergiyi doğuran olay ve bu olaya, ilişkin muamelelerin gerçek mahiyeti esastır. Vergiyi doğuran olay ve bu olaya ilişkin muamelelerin gerçek mahiyeti yemin hariç her türlü delille ispatlanabilir. Şu kadar ki, vergiyi doğuran olayla ilgisi tabii ve açık bulunmayan şahit ifadesi ispatlama vasıtası olarak kullanılamaz. Iktisadi, ticari ve teknik icaplara uymayan veya olayın özelliğine göre normal ve mutad olmayan bir durumun iddia olunması halinde ispat külfeti bunu iddia eden tarafa aittir."

9 Hukuk yargılamasında kesin ispat araçlarından biri olan "Yemin" 6100 Sayılı Hukuk Muhakemeleri Kanunu'nun 225. maddesinde düzenlenmiştir.
} 
Vergi davası, sadece hukuki konulardan kaynaklı ise hâkim bunu kendi hukuk bilgisi ile çözmek zorundadır. İşlemin yetki, șekil, sebep, konu ve maksat unsurlarından birinde sadece hukuk bilgisi ile "hukuka aykırıllğın" tespit edilmesi halinde bilirkişi incelemesine gidilemez. Bir idari işlemin yetki ve şekil unsurları bakımından bilirkişi incelemesi yapılamaz. Ancak işlemin sebep, konu ve maksat unsurlarının hukuka uygunluk denetimlerinde, işlemin temelinde maddi bir olayın da bulunması durumunda salt hukuki bir inceleme yeterli olmayabilecektir. İdari işlemin kamu yararına uygun olup olmadığına ilişkin iddiaların da maddi bazı olgulara dayalı olması durumunda kamu yararının tespiti de ancak bu olguların gerçekliği ile mümkün olduğunda, idari yargı yerleri bilirkişi incelemesine ihtiyaç duyabilirler (Yasin, 2015: 110-113). Re'sen araştırma yetkisinde sıklıkla karşılaşılan konu, hâkimin gerektiğinde bilirkişiden yararlanmak suretiyle inceleme yapılmasına ve bu incelemeyi yapacak bilirkişi seçimine de re'sen karar verebilmesidir (Aslan, 2001: 56). Bilirkişi incelemesi takdiri bir delildir. Bu delillerin karara etkisi mahkemenin takdirinde olduğundan bilirkişi raporunun karara etkisini de mahkeme tespit etmektedir. Ancak bilirkişi raporunun mahkeme tarafından ne şekilde takdir edileceği hususu doktrinde tartışmalı bir konudur (Yasin, 2015: 126).

Bilirkişi raporu hâkime, uyuşmazlığı çözmek için ihtiyaç duyduğu özellik arz eden teknik bilgiyi sağlama amacındadır. Hâkim bilirkişi raporunu özgürce değerlendirerek bu raporun aksine karar da verebilir. Ancak Danıştay tarafından bilirkişi raporunun gerekçe gösterilmeden kısmi de olsa kabul edilmemesi hukuka uygun bulunmamıştır (Yasin, 2015: 127128). Uygulamada hâkim verilen bilirkişi raporlarını tatmin edici ve yeterli bulmamışsa tekrar re'sen araştırma yetkisi kapsamında bilirkişi raporu isteyerek tereddütlerin giderilmesini sağlayabilir. Birden fazla bilirkişi raporu alınmış ve bu raporlar arasında çelişki varsa çelişki giderilerek karar verilir. Re'sen araştırma ilkesi gereğince hâkime geniş yetkiler verildiği görülse de hâkim bilirkişi raporunu kısmen de olsa dikkate alarak ve çelişkileri gidererek karar vermek durumdadır.

\subsubsection{Mükellef Haklarına İlişsin Sınırlar}

Mükellef hakları, "Genel haklar" ve "Özel haklar" olarak iki temel grupta ele alınmaktadır. Özel haklar; vergi kanunlarındaki özel konular, işlemler ve uygulamalar ile ilgili olup, vergi kanunlarının tatbikinde temel alınacak usul sürecine yoğunlaşmaktadır. Mükelleflerin, vergilemeye ilişkin karşılaştıkları özel konular ve işlemlerle ilgili sahip oldukları bu haklar; verginin tahsili, vergi uyuşmazlıklarının çözümü ve vergi denetimi aşamasındaki haklar olarak sayılmaktadır. Genel haklar ise; istisnasız tüm mükelleflerin sahip oldukları hakları ifade etmektedir ve vergi idaresi ile mükellef arasındaki ilişkilerde ortaya çıkmaktadır. Bu haklar; adil, eşit ve saygılı hizmet alma hakkı, bilgi alma hakkı, başvuru hakkı, vergilemede belirlilik hakk1, mükelleflere ait bilgilerin gizliliği hakkı, temsilci kullanma hakkı ve özel hayatın gizliliği hakkı olarak sayılabilir. Genel haklarda hiçbir sıralama ve hiyerarşi olmayıp, tüm mükelleflere vergi kanunlarının uygulanması, işleyiş̧i, yürütülmesi ve geçerliliği esnasında güvence sağlanmaktadır (Egeli ve Dağ, 2012: 133).

\section{a) Vergi Mahremiyeti Kapsamında}

Mükellef bilgilerinin gizliliği hakkı, vergi idaresine verilen yetkiler dâhilinde elde ettiği bilgileri gizli tutmasını ve bunların yalnızca kanunlarda belirtilen amaçlar doğrultusunda kullanılmasıdır. Bu nedenle vergi idareleri vergi mükellefleri ile ilgili elde ettikleri verileri gizli tutmakla ve güvenli bir şekilde saklamakla yükümlü tutulmuşlardır. Bu bilgiler sadece vergi kanunlarında gösterilen özel durumlar için kullanılmakta ve bunların dışında vergi idaresi mükellef bilgilerini hiçbir kişi ve kuruma verememektedir (Egeli ve Dağ, 2012: 134).

Vergi idaresi ile mükellefler arasındaki ilişkide mükelleflerle ilgili edinilen verilerin güvenliğinin sağlanması, mükelleflerle ilgili bilgilerin ifşa edilmemesi ve diğer kişiler lehine kullanılmamas1 konusu mükelleflerin "vergi mahremiyeti" olarak adlandırılan temel 
haklarındandır (Șenyüz, vd., 2016: 127). VUK 5. maddesi ${ }^{10}$ vergi mahremiyeti konusunu düzenlemekte ve buna uymak zorunda olanlar içinde vergi mahkemeleri, bölge idare mahkemeleri ve Danıştay'da görevli olanları da saymaktadır. Bu yasağın, kanunda yazılı kişilerin, bu görevleri bırakmaları halinde de devam edeceğini hükme bağlanmıştır.

VUK 5. maddesine göre; Vergi Mahkemeleri, Bölge İdare Mahkemeleri ve Danıştay'da görevli olanlar vergi mahremiyetine uyacaklardır. Ayrıca vergi mahremiyetine uymak zorunda olanlar arasında sayılan bilirkişilere hem idari aşamada hem de yargılama aşamasında ilgili yargı organlarınca gereksinim duyulduğunda başvurulabilmektedir (Ş.Kızılot ve Z.Kızılot, 2010: 274). VUK bir yargılama kanunu olmamasına rağmen HMK hükümleri gereğince, bir vergi davasında görev alan kişiler görevleri nedeniyle öğrendiği ve elde ettiği bilgileri ifşa edemez, kendisi ya da bir başkası lehine kullanamaz.

Vergi mahremiyetinin istisnası VUK 5. maddesinde yer almış bir konudur. Maddenin bütünü incelendiğinde" vergi mahremiyetine uymak zorunda olan "Vergi mahkemeleri, bölge idare mahkemeleri ve Danıştay'da görevli olanlar" 1 is istisna kapsamında açık bir şekilde yer almadığı ancak madde bütünü gereğince vergi mahremiyeti istisnası kapsamında kabul edilmesi gerektiği anlaşılmaktadır.

Vergi mahkemeleri, bölge idare mahkemeleri ve Danıştay hâkimlerinin, vergi mahremiyeti istisnası kapsamında re'sen araştırma ilkesi gereğince bilgi ve belge talebi sınırsız olmayıp talebin vergi mahremiyetini zedelemeyecek şekilde yapılması ve kullanılması gerekmektedir. Aksi takdirde hâkimler vergi mahremiyetini ihlal suçu ile karşı karşıya kalabileceklerdir. Vergi yargısındaki dava dosyalarının ayrıca adli yargıda da delil niteliği taşıması söz konusu olabilir. Bu durumdaki ihlal ise genel hükümlere göre cezalandırılır (Şenyüz, 2013: 411).

Vergi mükelleflerine ait açıklanmaması gereken ve vergi mahremiyeti kapsamında görülen bilgilerin, bir hakkın ispatlanması amacıyla mahkemelerce istenilmesi halinde, verilmesi zorunludur. Vergi mahremiyeti konusunda hâkimlerin de özellikle duruşmalı yapılan davalarda taraflarla birlikte gizli bilgi ve belgelerin ifşası riski konusunda gereken hassasiyeti göstermeleri beklenmektedir.

Sır olan bir bilgi veya belgenin sır sahibi dışındakilerle paylaşılması dahi ifşanın oluşması için yeterli görülmektedir. İfşa; sözlü, yazılı veya mimiklerle gerçekleşebilir. Belli bir ismin veya konunun anılması, verilen bilgiler sayesinde kişi veya konunun anlaşılması şeklinde de olabilir. Vergi gizliliği kapsamında olan bilgilerin doğrudan açıklanması şeklinde olabileceği gibi bir söylentinin veya bir tahminin teyidi şeklinde de olabilmektedir (Bayraklı, 1999: 48-49).

\footnotetext{
10 “Aşağıla yazılı kimseler görevleri dolayısıyla, mükellefin ve mükellefle ilgili kimselerin şahıslarına, muamele ve hesap durumlarına, işlerine, işletmelerine, servetlerine veya mesleklerine mütaallik olmak üzere öğrendikleri sirları veya gizli kalması lazım gelen diğer hususları ifşa edemezler ve kendilerinin veya üçüncü şahısların nef'ine kullanamazlar;

1. Vergi muameleleri ve incelemeleri ile uğraşan memurlar;

2. Vergi mahkemeleri, bölge idare mahkemeleri ve Danıştay'da görevli olanlar;

3. Vergi kanunlarına göre kurulan komisyonlara iştirak edenler;

4. Vergi işlerinde kullanilan bilirkişiler.

Bu yasak, yukarıda yazll kimseler, bu görevlerinden ayrllsalar dahi devam eder."

11 “...Ayrica, kamu görevlilerince yapılan adlî ve idarî soruşturmalar ile ilgili olarak talep edilen bilgi ve belgeler ....verilebilir. ...Bu takdirde kendilerine bilgi verilen kişi ve kurumlar da bu maddede yazıll yasaklara uymak zorundadirlar..

....tarafindan ilgili kanunları uyarınca mükelleflerden talep edilebilen, kurum ve kuruluşların görevleriyle doğrudan ilgili ve görevlerinin ifası için zorunluluk ve süreklilik arz eden bilgilerin, bu kurum ve kuruluşlara verilmesi vergi mahremiyetinin ihlali saylmaz. Bu durumda, kendilerine bilgi verilenler, bu maddede yazll yasaklara uymak zorunda olup, bu bilgilerin muhafazasını sağlamaya yönelik tedbirleri almakla yükümlüdürler. ...... Açılanan bu bilgiler ele alınarak mükelleflerin haysiyet, şeref ve haklarına tecavüz edilemez."
} 
IYYUK 17. maddesinin 4. fikrası gereğince, duruşma IYYUK'da belirtilen şartlarda davacı ve davalı tarafından istenebileceği gibi duruşma için öngörülen koşullara bağlı olmaksızın idari yarg1 yerleri re'sen duruşma yapılması kararı da alabilir. Ancak duruşma talebine rağmen duruşma yapılmadan hüküm kurulması, usul yönünden bozma nedeni olarak kabul edilmiştir (Odyakmaz, vd., 2012: 197).

Anayasanın 141. maddesine göre duruşmanın açıklığı ilkesi bir Anayasa ilkesidir. Duruşmanın açık yapılmasının anlamı isteyen her kişinin duruşma ile ilgili kurallara uyması şartıyla duruşmayı izleyebilmesidir. IYYUK 18. maddesine göre; genel ahlak ve kamu güvenliği yönünden zorunlu görülmesi halinde duruşmanın tamamı veya bir bölümü mahkemenin kararı ile gizli yapılabilir. IYUK, genel ahlakın ve kamu güvenliği kavramları "devletin güvenliği, yüksek menfaatleri ve yabancl devletlerle olan bu tür ilişkileri konusunda duruşmalar idarenin isteği üzerine gizli yapılmasına mahkemece karar verilebilir" şeklinde bir konuya işaret etmektedir (Gözübüyük ve Dinçer, 1999: 626-627). Vergi davaları açısından "genel ahlakın ve kamu güvenliğinin" anlamı açık bir şekilde tanımlanmalıdır. Böyle bir anlam vergisel işlemler açısından kamu güvenliği değil “vergi alacă̆ının güvenliği”"ni ifade edecektir. Dolayısıyla vergi hâkimi davaların duruşmalı yapılması gerektiğine karar verirken sadece vergi alacağını koruma amaçlı davranmamalı, davanın diğer tarafı olan vergi ödevlisini de onun haklarını gözetecek şekilde karar vermelidir. Çünkü vergi mahremiyeti gereğince davaların duruşmalı yapılması esnasında davayı izleyenler bakımından vergi mahremiyeti (davaya konu gizli bilgi ve belgelerin duruşma esnasında kullanılması gibi) ihlali riski mümkündür. Ayrıca re'sen araştırma ilkesinin sınırları bakımından gizli bilgi ve belgelerin bağlantılı ve dosyaların birleştirilmesi gibi durumlarda kullanılması da önemli bir konudur.

Danıştay ve bölge idare mahkemeleri ile tek hâkimli vergi mahkemesinde mahkeme veya hâkim kendiliğinden de duruşma yapılmasına karar verebilirse de böyle bir uygulama çok sınırlı kalmaktadır. Duruşmada taraflara önce davacıya sonra da davalı idare temsilcisine veya vekiline olmak üzere sırayla ikişer defa söz hakkı verilmektedir. Ancak ileri sürülen iddiaların bir tutanağa bağlanmaması bir eksiklik olduğu gibi dosyanın istinaf veya temyize gitmesinde veya heyet değişikliğinde söylenenlerin bu mercilere intikaline de engel oluşturmaktadır (Doğrusöz, 2016: 73).

Aleniyet ilkesi, yargılamada keyfiliği önleyerek kamu denetimine izin vermektedir (Gölcüklü, 1994: 216). Hukuk devletinin bir gereği olan aleniyet ilkesi, hâkimler üzerinde bir kamuoyu baskısı oluşturmakta ayrıca kamuoyunun yargıya güvenini sağlayarak yargılamanın adil ve tarafsızlığını ortaya koymaya çalışmaktadır. Anayasaya göre duruşmaların aleni yapılması ancak kamu güvenliği, genel ahlak ve küçüklerin korunmasına ilişkin özel kanunlarda belirtilen riskli durumlar nedeniyle kısıtlanabilir. Mükellefler açısından da özel durumlarına ait bilgileri vergi dairesiyle paylaşırken bu bilgilerin gizli kalmasını istemeleri en doğal haklarıdır. $\mathrm{Bu}$ nedenle hâkimin, yargı sürecinde aleniyet ilkesi ve vergi mahremiyeti arasındaki dengeyi kurmas1 gerekmektedir (Akman, 2012: 269).

\section{b) Bilgi ve İbrazdan Kaçınma ve Zorlanamaması Hakkı Kapsamında}

Vergi mükelleflerinin vergi hukuku kapsamında vergi mahremiyeti hakkı dışında sahip olduğu bazı hakları da söz konusudur. Bu haklar (Yavaşlar, 2012: 108-120);

-Bilgi ve ibrazdan kaçınma hakkı,

-Vergi ödevlisinin, bilgi ve ibraz için zorlanamaması hakkı,

-Katılımcı yakınlarının bilgi, yemin ve ibrazdan kaçınma hakkı,

-Diğer kişilerin bilgi ve ibrazdan kaçınma hakkı,

-Meslek sırrını koruma amacıyla bilgi ve ibrazdan kaçınma hakkı. 
Vergi mükellefinin sayılan bu haklar kapsamında vergi hâkiminin re'sen araştırma ilkesi gereğince isteyeceği bilgi ve belgeleri vermekten imtina edebileceği doğaldır.

Anayasa'nın 38. maddesinin 5. fikrasında; "hiç kimsenin, kendisini ve kanunda gösterilen yakınlarını suçlayan bir beyanda bulunmaya veya bu yolda delil göstermeye zorlanamayacă̆ ” belirtilmiştir. Vergi hâkimi vergi ödevlisinin bu hak sinırları dâhilinde bilgi ve belge edinebilecek ve bu bilgi ve belgeler kapsamında davaya yönelik olarak hüküm kurabilecektir.

\section{c) Susma Hakkı Kullanılması Kapsamında}

Anayasa Mahkemesinin 27.9.2012 tarihli E.2012/4, K.2012/130 say1l kararında, "hiç kimsenin, kendisini ve kanunda gösterilen yakınlarını suçlayan bir beyanda bulunmaya.... zorlanamayacă̆l " belirtilmiştir. Avrupa İnsan Hakları Sözleşmesi (AİHS)'nde de adil yargilanma kapsamında "susma ve kendini suçlamama" hakkına yer verilmesiyle susma hakkının açıkça güvence altına alındığı görülmektedir (RG, www.resmigazete.gov.tr>2013/12 Erişim Tarihi:10.01.2021). Avrupa İnsan Hakları Mahkemesi içtihatlarında, susma hakkı kapsamında, genel olarak devletin, bireyin kendini suçlamaya zorlayamayacağını kabul etmekte ancak cezai olmayan amaçlar için ise devletin bilgi edinme hakkına da saygı duymaktadır (Berger, 2007: 514-533).

İdari yargılama usulünde de davacının, susma hakkından yararlanması mümkündür. Örneğin, kendisi hakkında bir ceza soruşturması sonucunu doğuracak bir belgenin mahkemeye sunulmasından veya bir bilginin verilmesinden davacı susma hakk1 kapsamında imtina edebilecektir. Re'sen araştırma ilkesi çerçevesinde, tarafların yargılamadaki aktif katılımı dışında hâkimin, ispat yükünü dağıtması durumunda, ispat yükü üzerinde olan davacının susma hakkını kullanmasında hukukî bir engel yoktur. Susma hakkının davacının aleyhine yorumlanamayacağı kuralı geçerlidir. Ancak mahkemenin re'sen araştırma yetkisine rağmen yargilama sürecinde, davacı tarafından sunulmayan bilgi ve belgeler esas alınarak ileri sürülen iddiaların ispatı sağlanamadığı takdirde susma hakkı davacı lehine de dönmeyecektir. Mahkemenin susma hakkı nedeniyle davacı tarafından ibraz edilmeyen bilgi ve belgelere, re'sen araştırma yetkisini kullanarak ulaşması durumunda, bu bilgi ve belgeler davaya konu olayda mahkemece değerlendirilecektir. Ayrıca susma hakkından yargılama aşamasında vazgeçen mükellefin dosyaya ibraz ettiği bilgi ve belgelerin mahkemece değerlendirilmesi söz konusu olacaktır (Kağıtcıŏ̆lu, 2018: 139-150).

Susma hakkı vergi ve idari yargılamada hâkimin re'sen araştırma ilkesi gereğince bilgi ve belge temini konusunda sorunlu bir konudur.

\subsubsection{Mücbir Sebeplerin Varlı̆̆ına İlişkin Sınırlar}

VUK 13. maddesi mücbir sebepleri düzenlemektedir. Mücbir sebepler maddede; "vergi ödevlerinden her hangi birinin yerine getirilmesine engel olacak derecede ağı kaza, ăğr hastalık ve tutukluluk; vergi ödevlerinin yerine getirilmesine engel olacak yangin, yer sarsintısı ve su basmast gibi afetler; kişinin iradesi dışında vukua gelen mecburi gaybubetler; sahibinin iradesi dışındaki sebepler dolayısiyle defter ve vesikalarının elinden çıkmış bulunması; gibi haller" şeklinde sayılmış olup, re'sen araştırma ilkesinin sınırını oluşturmaktadır. IYYUK 21. maddesine göre; "dilekçeler ve savunmalarla birlikte verilmeyen belgeler, bunlartn vaktinde ibraz edilmelerine imkan bulunmadığına kanaat getirilirse, kabul ve diğer tarafa tebliğ edilir." Hükmü ile belirtilen durumun vergi davaları açısından öncelikle mücbir sebeplerin varlığı ile açıklanması gerekmektedir.

Maddede sayılan mücbir sebepler nedeniyle vergi hakiminin ilgililerden re'sen araştırma ilkesi gereğince bilgi, belge, dosya, evrak gibi istemi anlamını yitirecektir. Dolayısıyla vergi hakimi, belgelerin mahkemeye sunulamaması durumunda davacı iddiaların doğruluğunu kabul 
etmek zorunda kalacak ve mahkemeye sunulamayan bilgi ve belgeler dikkate alınmayarak dosyada var olan somut kanttlarla hüküm kurulabilecektir.

\subsubsection{Zamanaşımına İliş̧kin Sınırlar}

VUK $253^{12}, 254^{13}, 255^{14}$.maddeleri ile diğer $\operatorname{kanun}^{15}$ ve yönetmeliklerde ${ }^{16}$ yer alan hükümler gereğince ilgili oldukları takvim yılının üzerinden belli bir süre geçmiş (örneğin 5 yıllık zamanaşımı süresi) bulunan belge, defter ve evrakların temini tarafların mevcutlarındaki varlığına bağlı olduğundan süre açısından bir sınırın oluştuğu görülecektir (İbiş, 2013: 97). Dolayısıyla vergi hâkimi re'sen araştırma ilkesi gereğince, zamanaşımına uğramış belge ve defterleri sunmasını mükelleften veya duruma göre idareden isteme ve getirtme konusunda sinırlı kalacaktır.

\subsection{Diğer Sınırlar}

\subsubsection{Hâkimin Keyfi Davranamamasına İlişkin Sınırlar}

Re'sen araştırma ilkesinin sınırlarından biri de vergi hâkiminin keyfi davranma yasağıdır. Bu kısıt, re'sen araştırma ilkesinin hâkim bakımından bir yetki olmakla birlikte bir görev olmasından da kaynaklanmaktadır. Danıştay kararlarında da belirtilen sınır gereğince, (örneğin, bilirkişi dinlenmesine izin vermeyen veya keşif yapılması gerektiği halde keşfi yaptırmayan, taraflardan birinin savunmasını vermeme gerekçesiyle maddi olayı re'sen araştırmayan veya re'sen araştırma yaparken usul kurallarına uymayan hâkim) hâkimin keyfi tutumları kabul edilmeyecektir.

Danıştay 3. Dairesi, 25.10.1989 tarihli E.89/452, K.89/2340 sayılı kararında, vergi mahkemesince, duruşma yapmadan sadece taraflardan birinin çağrılarak bilgisine başvurulmasına imkân tanıyacak bir hüküm bulunmamaktadır. Bu durumda vergi mahkemesince re'sen araştırma ve inceleme yapılırken “....kanunda gösterilen esaslar çerçevesinde bir araştırma yapılmaksızın duruşma dışında mükellefin bilgisine başvurulmasında isabet görülmemiştir" diyerek durumu "araştırmanın keyfi bir biçimde yürütülmesi" olarak değerlendirmiş ve ilk derece mahkemesinin kararını bu gerekçe ile bozmuştur (Gözübüyük ve Dinçer, 1999: 634).

Danıştay 7. Dairesinin 13.2.1984 tarihli E.83/1299, K.84/251 sayılı kararında; “....ara kararında, karar gereğinin yerine getirilmemesi halinde bu durumun karar üzerindeki etkisi 2577 sayll Kanunun 2.maddesinin 2.fikrasi uyarınca kararda belirtilmesi gerekirken bu usul hükümlerine uyulmamıștır....hususları araştırılarak....sonuca göre karar verilmesi gerekirken bu hususlar araştırılmaksızın davanın karara bağlandiğı anlaşılmaktadır" ifadesiyle vergi mahkemesinin kararının bozulmasına hükmetmiştir (Gözübüyük ve Dinçer, 1999: 643). Danıştay 3. Dairesinin E.1989/1724, K.1990/3422 sayılı kararında, “ her ne kadar, idari yarglda re'sen araştırma ve inceleme ilkesi geçerli ise de bu olgunun mahkemenin araştırmalarını keyfi bir şekilde yürütebileceği anlamına gelmez" ifadesine yer vermiştir (Özkan, 2005: 69). Danıştay 3. Dairesi, 20.11.2001 tarihli E.2000/5192, K.2001/4408 sayılı kararında da dava esnasında mükellefin defter ve belgelerini ibraz etmemesi durumunda hâkimin re'sen araştırma yapması

\footnotetext{
12 “...defter tutmak mecburiyetinde olanlar, tuttukları defterlerle ü̧̈üncü kısımda yazıll vesikalarl...beş yll süre ile muhafaza etmeye mecburdurlar."

13 “...defter tutmak mecburiyetinde olmayanlar, 232, 234 ve 235.maddeler mucibince almaya mecbur olduklarl fatura ve gider pusulası ve müstahsil makbuzlarını tarih sirası ile ...beş yıl süre ile muhafaza etmeye mecburdurlar."

14 "Mükellefler ....aldiklarl vergi karnelerini, işin devam ettiği..... sürece muhafaza ederler."

${ }^{15}$ 28.9.1988 tarihli 3473 sayıl1 "Muhafazasina Lüzum Kalmayan Evrak Ve Malzemenin Yok Edilmesi Hakkında Kanun Hükmünde Kararnamenin Değiștirilerek Kabulü Hakkında Kanun"

16 8.10.2019 tarihli 30922 sayılı RG'de yayımlanarak yürürlüğe giren “Devlet Arşiv Hizmetleri Hakkında Yönetmelik”
} 
gerektiğini belirtmiş ve bu araştırmanın gerçekleştirilmeyerek keyfi davranıldığı belirtilmiştir (Ergün, 2006: 17).

Vergi yargısında re'sen araştırma ilkesi gereğince "bilirkişis" ve "keşif" gibi kanıtlar davanın niteliğine göre yaygın şekilde kullanılan yöntemlerdir. IYYUK, bilirkişi ve keşif gibi kanıtlar için HMK'dan yararlanmaktadır. Danıştay 4. Dairesinin 13.12.1961 tarih ve E.60/4394, K.61/3823 sayılı kararında da VUK'ta evrak üzerindeki imzaların doğrulanması için nasıl bir usul izleneceğine dair özel bir yöntem gösterilmemiş olması nedeniyle HMK hükümlerinin uygulanması gerektiğine hükmetmiştir (Gözübüyük, 2006: 460). Karardan da görüleceği gibi VUK'ta hüküm bulunmayan durumlarda bile hâkimin keyfi davranması söz konusu olamayacak ve diğer kanunlardaki hükümler dâhilinde re'sen araştırmayı gerçekleştirecektir.

Re'sen araştırma yapma yetkisine sahip hâkimin, tarafların sunduğu dava malzemeleri ile kısıtlanmaması vergi hâkiminin takdir hakkını istediği gibi kullanabileceği anlamına gelmemelidir. Dolayısıyla vergi hâkimi, davayla ilgili olarak istenmesi gereken bilgi ve belgeleri ilgili yerlerden ancak kanunlarda belirtilen usul ve esaslar çerçevesinde gerçekleştirmelidir.

\subsubsection{Danıştay İçtihatları İle Oluşan Sınırlama}

Danıştay içtihatları, idarenin hukuki işleminin kapsamını ve yönünü tespit ederek, birbiriyle benzeşen tüm olgu ve durumlar için kabul edilen genel ve nesnel kaideler ve ilkeler öngörmektedir (Duran,1972: 439). Yargılama hukuklarının oluşturulmasında önemi ve anlamı büyük olan içtihatların vergi yargısı bakımından da önemi yadsınamaz. Re'sen araştırma ilkesinin kanundaki yazılı kuramsal yapısıyla birlikte pratikte de yazılı olmayan birçok konuyla karşılaşılmakta ve Danıştay'ın bu konulardaki benzer kararları ve içtihatları önemli rol oynayarak yol gösterici olmaktadır.

Danıştay 5. Dairesinin, 08.12.1987 tarihli E.1985/815, K.1987/1723 sayıl1; “...re'sen araştırma ilkesi, dava konusu işlemin tesisine esas olarak gösterilen, hukuki nedenin var olup olmadı̆̆ının araştırılması, dayanağ gibi taraflarca öne sürülmemiş olsa dahi idare hukukunda kamu düzenine ilişkin olduğu tartışması kabul edilmiş olan görev, yetki, süre gibi konuların incelenmesi seklinde de anlaşıllır..." kararıyla (Aslan, 2001: 55) dayanağı olan/olmayan tüm konularda hâkimin re'sen geniş yetkilerle donatıldığını ifade etmiş̧ir ancak hâkim araştırma ve incelemelerini keyfi bir şekilde yürütemeyecektir.

Danıştay, kanunda gösterilmeyen bir yöntemin yarg1 organlarınca re'sen araştırma ilkesine dayanılarak keyfi şekilde uygulanamayacağına vurgu yapmıştır. Danıştay 3. Dairesinin E.1989/452, K.1989/2340 kararıyla; "duruşmada tarafların dinleneceği hükme bağlanmış, ancak duruşma yapmaksızın taraflardan birinin çağrılması suretiyle bilgisine başvurulmasını mümkün kılacak bir hükme yer verilmemiştir" ifadesiyle konuya açıklık getirilmiştir (Özkan, 2005: 69).

IYYUK 20. maddesine göre davacı iddiasını ispatlamak amaciyla dairede bulunan işlemlere ait dosyanın teminini ya da delillerin tespitinin belirlenmesini talep edebilir. İdare istenen bilgi ve belgeleri mahkemeye vermezse veya kaybetmişse Danıştay konuyu bizatihi yorumlayacaktır. Danıştay'ın böylesi durumları ne şekilde değerlendireceği ise açık değildir. Ancak Danıştay oluşturulan içtihatlar doğrultusunda ve hukuki kurallar çerçevesinde karar verecektir. Danıştay 9. Dairesinin 16.10.1973 tarihli E.72/436, K.73/1977 sayılı “...iki ara kararına rağmen davalı vergi dairesince durumun açıklığa kavuşturulamayışı veya yapılan işlemin kanuniliğini saptayan belgelerin mahkemeye ibraz edilmemesi karşısında davacı iddialarının doğruluğunun kabulü gerekli görülmüştür” kararı konuya açık bir örnektir (Gözübüyük ve Dinçer, 1999: 3,4,642). Bu karar, Danıştay'ın sunulmayan/sunulamayan belgeler karşısında davacının iddialarıyla yetinerek konuyu bizatihi yorumlamak suretiyle karar verdiğinin ve yargıda oluşabilecek aksamaları bertaraf etme yoluna gittiğinin bir göstergesidir. 
Danıştay, E.1996/1345, K.1996/2819 sayılı kararında mahkemeye verilmeyen bilgi ve belgelere dayanarak değil, dosyada bulunan deliller doğrultusunda hüküm kurulabileceğini belirtmiştir. Ancak Danıştay Kanunu'nun 61. maddesinin 2. fikrasında, her çeşit bilginin istenebileceği yönündeki hüküm, temyiz amaçlı bakılan dosyalarda Danıştay’ın temyiz yetkileriyle kısıtlanmıştır (Özkan, 2005: 56-30).

\subsubsection{Re'sen Araştırma İlkesinin Diğer Yargılama İlkeleriyle Sınırlı Oluşu}

Yargılama ilkeleri birbirleriyle yakın ilişki içinde bulunmakla birlikte ilkelerin zaman zaman uygulamada birbiriyle ters düştüğü söylenebilir. Bu ilkelerden bazıları şu şekilde ele alınabilir:

Re'sen araştırma ilkesi öncelikle, Anayasal ilkelerle sınırlı bir ilkedir. AİHS'de belirtilen ilkelerle sınırlı olacaktır. Ayrıca vergi davalarının kendine özgü yapısı nedeniyle vergi kanunlarında yer alan ilkelerin de göz önünde bulundurulması zorunludur. Re'sen araştırma ilkesi özellikle hukuksal denetim ilkesiyle sınırlı olduğu gibi yerindelik denetiminin yapılamayacağı ilkesiyle de sınırlıdır. Re'sen araştırma ilkesi, vergi yargılama hukukunda egemen olan diğer kurallar da dikkate alınarak işletilmelidir. Örneğin Danıştay 3. Dairesinin E.1989/1724, K.1990/3422 sayılı kararında, “....vergi mahkemelerinde yazıll yargılama usulünün uygulanacă̆l ve incelemenin evrak üzerinden yapılacağl belirtilmiştir.......kişsinin "sözlü" olarak ifadesine başvurmasında isabet görülmemiştir" (Özkan, 2005: 69) hükmüyle re'sen araştırma ilkesi gereğince bilgi isteminin "yazılılık ilkesi" çerçevesinde yapılması gerektiği belirtilmiştir.

Re'sen araştırma ilkesi, adil yargılanma ilkesi kapsamında makul sürede yargılanma hakkı gözetilerek işletilmelidir. Hâkimin, re'sen araştırma ilkesi gereğince yapacağı inceleme, bilgi ve belge istemi sürelerinin gereksiz şekilde uzatılmadan makul süre gözetilerek hareket etmesi beklenir. $\mathrm{Bu}$ durum özellikle o ülkede adalete olan güvenin sarsılmaması bakımından önemlidir. Özellikle Türkiye Cumhuriyeti Adalet Bakanlı̆̆ı'nın "hedef süre" uygulamasına geçmesiyle davanın taraflarında, belirlenen hedef süre içinde davanın sonuçlanacağı beklentisi yargı organlarını psikolojik baskı altında tutabilir. Dolayısıyla re'sen araştırma ilkesi gereğince, bilgi, belge istemleri, bilirkişi, uzman görüşleri alınması gibi konularda makul sürede yargılanma hakkının zedelenmeyecek şekilde dikkat edilmesi önemli bir konudur.

Re'sen araştırma ilkesi gereğince bilgi talebi konusunda sınırı, esasen ölçülülük ilkesi oluşturmaktadır. $\mathrm{Bu}$ bakımdan idare, vergilendirme yönüyle gerek duyulmayan bilgileri isteyemeyeceği gibi, daha basit diğer yollar ve şahıslardan elde edebileceği bilgileri de talep edemeyecektir. Doğal olarak sahip olunmayan veya hiçbir şekilde sahip olunamayacak bir bilgiyi araştırıp bulup getirmesi hiç kimseden istenemez (Yavaşlar, 2016: 113-127).

Tasarruf ilkesi, tarafların yargılamayı başlatma, dava konusunu belirleme ve sonlandırılabilmesi üzerine etki edebilme iktidarıdır. Dava ancak tarafın talebi üzerine görülebilir, ihtilaf konusu sadece davacı tarafindan belirlenebilir, davadan feragat, davayı kabul gibi konular tasarruf ilkesi içinde ele alınır (Alangoya, vd., 2009: 182-183). Bu konular re'sen araştırma ilkesini gereğince hâkimin aktif hareketini kısmi de olsa sınırlamaktadır.

\section{SONUÇ}

Türk hukuk sistemi içinde kamu hukukunun bir alt dalı olan vergi yargısının taraflarından biri doğal olarak vergi idaresidir. İdari yargıda olduğu gibi vergi yargısında da idarenin davanın diğer tarafına göre üstün konumda olması, kamu yararının varlığ1 ve önemi, bilgi, belge, diğer kaynak ve imkânlara ulaşımın kolaylığı gibi konularda yargılama açısından taraflar arasında eşitsizliği ortaya çıkarabilmektedir. $\mathrm{Bu}$ nedenle taraflar arasında eşitliğin sağlanabilmesi ve yargılamanın sağlıklı yürütülerek doğru ve adil kararlar alınabilmesi amacıyla 
hâkimlere bazı imkânların verilmesi gerekmektedir. Re'sen araştırma yetkisinin verilmesi bu amaçla ortaya çıkan bir yetki olup ayrıca görev olarak hâkimlere tevdi edilmiştir. Re'sen araştırma; vergi yargılamasında ve genellikle idari yargılama usulünde, hâkimin ispat ve delillerin incelenip, araştırılarak ortaya çıkarılmasında ve davanın yürütülmesinde re'sen hareket etme yetkisidir. İlgili kanunlarda ve uygulamada re'sen araştırma yetkisine geniş bir yer verildiği ve hâkimin de oldukça geniş yetkilerle donatıldığı görülmektedir. Ancak bu geniş yetkilerin bazı sınırlarının olması yargılamanın sağlıklı bir şekilde sonuçlanmasına hizmet edecektir.

Vergi uyuşmazlıkların yargısal çözümünde Vergi Mahkemeleri, Bölge İdare Mahkemesi ve Danıştay görevlidir. Bu yargı organlarında görevli hâkimler, bir kamu kaynağı ve alacağı konumunda olan vergi, resim, harç vb. gelirleri, doğru bir şekilde ve zamanında devlet bütçesine kazandırılabilmesine ve kamu hizmetlerinin zamanında gerçekleştirilmesine katkı sağlamaktadırlar. Bununla birlikte genellikle davanın diğer tarafında yer alan vergi ödevlisinin de doğru vergi borcu ile muhatap olmasını, idarenin eylem ve işlemleri konusunda mağdur edilmemesini ve korunmasını sağlayacaktır. Vergi hâkimi bu görevleri yerine getirirken davayı aydınlatabileceği ve doğru karar verebileceği bilgi, belge vb. evrakların teminini taraflarla birlikte üstelenmiş durumdadır. Hatta bu konuda inisiyatifi genellikle hâkim kendisi re'sen kullanarak davayı daha basit ve çabuk sonuçlandırma yoluna gitmektedir.

Re'sen araştırma ilkesinin Anayasa'nın 125. maddesiyle esasen idari yargının görev alanının da belirlendiği idarenin her çeşit eylem ve işlemlerin araştırılması esnasında söz konusu olduğu söylenebilir. Ancak hâkime verilen re'sen araştırma yapabilme hak ve görevinin uygulanabildiği alan çok kapsamlı olmakla birlikte bu ilke ile hâkime sınırsız hak ve yetki tanınmamıştır.

Re'sen araştırma ilkesinin sınırları açısından öncelikle idarenin yargısal denetiminin Anayasal sınırları dikkate alınmalıdır. İdarenin yargısal denetiminin sınırlarının Anayasa'da; idarenin yargısal denetiminin hukuka uygunluk denetimiyle sınırlandırılması; idari işlem veya eylem özelliğinde ve takdir yetkisini ortadan kaldıracak özellikte hüküm kurulamaması; yerindelik denetimine izin vermemesi ve nihayetinde yürütme görevinin yasalarda gösterilen şekil, usul ve esaslara göre yerine getirilmesini sinırlayacak nitelikte hükümler verilememesi şeklinde belirlendiği görülmektedir.

Re'sen araştırma ilkesini kısıtlayan hükümler, ayrıca ilkenin uygulama kapsamının tespitini de sağlamaktadır. Re'sen araştırma ilkesini kısıtlayıcı özellikteki başlıca hükümler IYUK'ta yer almıştır ve 20. maddesinde doğrudan ifade edilen, devletin güvenliği veya yüksek menfaatlerine zarar verebilecek nitelikteki bilgi ve belgelerin hâkim tarafindan istenmesinin sınırı çizilmiştir.

Bununla birlikte re'sen araştırma ilkesi, hukuka uygunluk denetimi ile sınırlıdır. Hâkimin bu yetkiyi, yerindelik denetimi yapamayacak şekilde ve idarenin takdir yetkisini kaldıracak nitelikli yargı kararı verilememesine yönelik sınırlar kapsamında kullanması gerekir. Yine tarafların sürenin bitimi sonrasında yapacakları savunmalara veya ikinci dilekçelere dayanarak hak iddia edememelerine ilişkin sınırlar, dava dilekçesinde ileri sürülen iddia ve taleple sınırlı1ık, şekil ve usûl kurallarına ve kanuni sürelerle sınırlılık bu kapsamda dikkate alınan konulardır.

Vergi yargısı açısından VUK 3. maddesinde belirtilen "İspat" konusu re'sen araştırma ilkesinin sınırını vergi davaları yönüyle ortaya koymaktadır. Hâkimin VUK gereğince "yemin" ispat aracına başvuramaması re'sen araştırma ilkesinin sınırını oluşturmaktadır. Aynı maddede belirtilen; vergiyi doğuran olayla doğal bir şekilde ilgisi ve açıkça muhatabı bulunmayan şahit ifadesi ispatlama aracı olarak kullanılamamaktadır. Bu hüküm, hâkimin re'sen araştırma yetki ve görevini, sadece vergiyi doğuran olayla doğal olarak ve açık bir şekilde ilgisi olan şahidin dinlenmesi yönüyle sınırlandırmaktadır. 
VUK gereğince re'sen araştırma ilkesine getirilen bu sınırlamalar yanında dolaylı olarak hâkim, yargılama sırasında vergi mahremiyetine ve mükellef haklarına hassasiyet göstermek suretiyle hareket etmelidir. Ayrıca VUK'da belirtilen zamanaşımı süreleri ve mücbir sebeplerin varlığı halinde de hâkim re'sen araştırma ilkesi gereğince isteyeceği bilgi ve belgeleri teminde sinırlı olacaktır.

Anayasa'da, IYUK'da ve VUK'da re'sen araştırma ilkesine yönelik dolaylı ve dolaysız sınırlamalar dışında diğer sınırlamaların da olduğu uygulamada görülmektedir. Örneğin mahkemeler tarafindan bu ilkenin işletilmesi sırasında Danıştay içtihatlarıyla ortaya çıkan sınırlamaları da bulunmaktadır. Yargılama sırasında re'sen araştırma ilkesinin, diğer yargılama ilkeleriyle çatışır şekilde kullanılmaması ve işlerliğini kaybettirmeyecek nitelikte uygulanması gerekmektedir.

Re'sen araştırma ilkesi, vergi yargısı hukukumuzda yargı tekniği yönüyle önemli bir ilke olarak addedilip kapsamlı biçimde değerlendirilmiş olması bakımından olumlu bir yaklaşımdır. $\mathrm{Bu}$ ilkenin başarılı biçimde uygulanmasıyla aynı zamanda anayasamızda yer alan vergilerin kanuniliği ve vergide adaletin sağlanmasına da katkı söz konusu olmaktadır. Ancak bu ilkenin işletilmesinde özellikle hâkimin keyfi davranmaması ve amacını aşan nitelikte bilgi, belge isteminin sınırlandırılmasına getirilecek düzenlemelerin açık, anlaşılır ve dolaysız şekilde belirlenmesine özen gösterilmesi vergi yargısının kendine has yapısı ve tekniği açısından büyük önem arz etmektedir.

\section{Araștırma ve Yayın Etiği Beyanı}

Çalışma bilimsel araştırma ve yayın etiği kurallarına uygun olarak hazırlanmıştır.

\section{Yazarların Makaleye Katkı Oranları}

Yazarların makaleye katkıs $\% 50-\% 50$ 'dir.

\section{Çıkar Beyanı}

Yazarlar açısından ya da üçüncü taraflar açısından çalışmadan kaynaklı çıkar çatışması bulunmamaktadır. 


\section{KAYNAKÇA}

Adalet Bakanlığı, Hukuk Sözlüğü, https://sozluk.adalet.gov.tr/Harf/R Erişim Tarihi:12.01.2021.

Akkaya M. (2002). Vergi Hukukunda Ekonomik Yaklaşım, Turhan Kitabevi, Ankara.

Akman İ.S. (2012). Vergi Mahremiyetini İhlal, Ankara Üniversitesi Sosyal Bilimler Enstitüsü, Doktora Tezi, Ankara.

Alangoya, H.Y. (1979). Medeni Usul Hukukunda Vakıaların ve Delillerin Toplanması, İstanbul, aktaran Ş. Özkan, a.g.t, 2015 .

Alangoya, H.Y., Yıldırım M.K. \& Yıldırım N.D. (2009). Medeni Usul Hukuku Esasları, Beta Basım, 7.Baskı, İstanbul.

Aslan Z. (2001). Türk İdari Yarg1 Sisteminde Re'sen Araştırma İlkesi, İstanbul Üniversitesi Siyasal Bilgiler Fakültesi Dergisi, No:23-24, İstanbul.

Bayraklı H.H. (1999). Türk ve Alman Vergi Hukukunda Vergi Gizliliğine Uymama Suçu, Afyon Kocatepe Üniversitesi Yay.

Bayraklı H.H. (2000). Vergi Yargilama Hukuku, Celepler Matbaa,7.Bask1, Trabzon.

Berger M. (2007). Self-Incrimination and the European Court of Human Rights: Procedural Issues in the Enforcement of The Right to Silence, European Human Rights Law Review, Issue 5, aktaran M. Kağıtçığlu (2018).

Biyan, Ö. (2012). Türk Vergi Hukukunda İspat-Delil, Adalet Yayınevi, Ankara.

Candan, T. (2011). İdari Yargılama Usulü Kanunu, Adalet Yay., 4.Bask1, Ankara.

Çağlayan, R. (2004). İdari Yargı Kararlarının Sonuçları ve Uygulanması, Asil Yayın, 3.Baskı, Ankara.

Çağlayan, R. (2011). İdari Yargılama Hukuku, 1.Baskı, Ankara.

Doğrusöz, B. (2016). Savunma Hakkı Açısından Vergi Yargısı ve Yargılama Usulünün Değerlendirilmesi, I. Ulusal Vergi Yargıs1 Paneli 28.02.2016, Vergi Müfettişleri Derneği, Epamat Basım, Ankara.

Duran, L. (1972). Danıştay'ın İçtihatları Birleştirme Uygulaması, Ankara Üniversitesi Siyasal Bilgiler Fakültesi Dergisi, Ankara, C.27, S.3, s.439 aktaran Serkan Kızılyel, Danıştay İçtihatları Birleştirme Usulünün Formel İşleyiş̧i Üzerine, TBB Dergisi, S.119, 2015.

Egeli, H. \& Dağ, M. (2012). Türk Vergi Hukuku Açısından Mükellef Haklarının Değerlendirilmesi, Maliye Dergisi, Temmuz-Aralık, S.163, Ankara.

Ergün, Ç.E. (2006). Vergi Yargılamasında Re'sen Araştırma İlkesi, Ankara Üniversitesi Hukuk Fakültesi Dergisi, Cilt:55, Say1:2, Ankara.

Gerçek A. (2010). Vergi Hukuku Alanındaki Takdir Yetkisinin Kullanılmasında İdarenin ve Memurun Sorumluluğu, Uludağ Üniversitesi İktisadi ve İdari Bilimler Fakültesi Dergisi, Cilt XXIX, Say1 2, Bursa.

Gölcüklü, F. (1994). Avrupa İnsan Hakları Sözleşmesi’nde Adil Yargılama, Ankara Üniversitesi Siyasal Bilimler Fakültesi Dergisi, C.49, S.1-2, Ankara.

Görkem, N.A. (2008). Türk Vergi Yargı Sisteminde Delil, Gazi Üniversitesi Sosyal Bilimler Enstitüsü Maliye ABD Yüksek Lisans Tezi, Ankara.

Gözübüyük, A.Ş. (2006). Yönetsel Yargı, Turhan Kitabevi, 24.Baskı, Ankara.

Gözübüyük, A. Ş. \& Dinçer G. (1999). İdari Yargılama Usulü, Turhan Kitabevi, 2.Bask1, Ankara.

Güneş, T.K. (2017). Türk Vergi Usul Hukuku'nda Re'sen Araştırma İlkesi, Seçkin Yayıncılık, Ankara.

İbiş, R. (2013). Vergi Yargılamasında Re’sen Araştırma, Yaklaşım Yayıncılık, Ankara.

Kağıtcıoğlu, M. (2018). Kurgudan Gerçekliğe Uzanan Bir Tartışma Alanı: Susma Hakkının İdare Hukukunda Yeri Var midır?, TBB Dergisi, Sayı:134.

Kalabalık, H. (2013). İdari Yargılama Usulü Hukuku, Sayram Yayın, 5.Baskı, Konya.

Kaya C. (2011). İdarenin Takdir Yetkisi ve Yargısal Denetimi, On İki Levha Yayın, 10.Bask1, İstanbul.

Karakoç, Y. (2019). Vergi Yargılaması Hukuku, Anadolu Üniversitesi Yayın No:2951, Eskişehir.

Karavelioğlu, C. (1999). İdari Yargılama Usulü Kanunu Şerhi, 4.Baskı, Trabzon, aktaran Şenyüz, Yüce, Gerçek, (2016). Vergi Hukuku, Ekin Basım, 7.Bask1, Bursa. 
Kumrulu, A. (1989). Vergi Yargılama Hukukunun Kuramsal Temelleri, Ankara.

Kuru, B. (2016). Medeni Usul Hukuku, Legal Yayınevi, 3.Bask1, İstanbul.

Kuru, B., Arslan, R. \& Yılmaz, M.A.E. (2011). Medeni Usul Hukuku, Yetkin Yayınc1lık, 22.Bask1, Ankara.

Kızılot, Ş. \& Kızılot, Z. (2010). Vergi İhtilafları ve Çözüm Yolları, 18.Baskı, Ankara.

Oğurlu, Y. (1998). Danıştay Kararları Işığında İdari Yargılama Usulünde Re'sen Araştırma İlkesi, Erzincan Hukuk Fakültesi Dergisi, C.2, S.1.

Odyakmaz, Z., Kaymak, Ü. \& Ercan İ. (2012). İdari Yarg1, Oniki Levha Yayıncılık, 8.Bask1, İstanbul.

Oktar S.A. (2010). Vergi Hukuku, Türkmen Kitabevi, 5.Bask1, İstanbul.

Öncel, M., Kumrulu, A. \& Çağan, N. (2008). Vergi Hukuku, Turhan Kitabevi, 18.Bask1, Ankara.

Özelçi A. (2018). İdari Yargıda Re'sen Araştırma ve İstemle Bağlılık İlkeleri Çerçevesinde Danıştay’ın İmar Hukuku İle İlgili Bir Kararının Tahlili, Fasikül Hukuk Dergisi, C:10, S:100, Ankara.

Özkan, Ş. (2005). Vergi Yargılama Hukukunda Re’sen Araştırma İlkesi, Ankara Üniversitesi Sosyal Bilimler Enstitüsü Kamu Hukuku ABD, Yüksek Lisans Tezi, Ankara.

Özmumcu, S. (2014). Türk Hukukunda Yargıtay Kararları Işı̆̆ında Re'sen Araştırma İlkesi, SDÜ Hukuk Fakültesi Dergisi MïHBİR Özel Sayısı, Medenî Usûl ve İcra-İflâs Hukukçuları Toplantısı XII. 18-19 Ekim 2014, C:4, S:2, Isparta.

Pekcanitez, H., Atalay O. \& Özekes M. (2007). Medeni Usul Hukuku, Yetkin Yayın, 6.Bask1, Ankara.

Resmî Gazete, www.resmigazete.gov.tr>2013/12 Erişim Tarihi:10.01.2021

Simil, C. (2015). Hâkimin Davayı Aydınlatma Ödevinin Sınırları, Dokuz Eylül Üniversitesi Hukuk Fakültesi Dergisi, Prof. Dr. Hakan PEKCANITEZ’e Armağan, C.16, Özel Sayı.

Sunay, S.Ş. (1997). İdari Yargılama Usulüne Hâkim Olan İlkeler Karşısında İspat ve Delil Hususları, Kazanc1 Yayınevi, İstanbul.

Şenyüz, D. (2013). Vergi Ceza Hukuku, Ekin Yayınları, 7.Baskı, Bursa.

Şenyüz D., Yüce M. \& Gerçek A. (2016). Vergi Hukuku, Ekin Basım, 7.Bask1, Bursa.

Tekbaş, A. \& Hayrullahoğlu, B. (2018). Vergi Uyuşmazlıkları Bakımından Makul Sürede Yargılanma Hakkı, Maliye Dergisi, Temmuz-Aralık, Sayı:175, Ankara.

Üstün Ü.S. (2006), Türk Vergi Hukukunda İdarenin Takdir Yetkisi, Selçuk Üniversitesi Hukuk Fakültesi Dergisi, C.14, S.1, Konya.

Üstün T.K. (2019). İdari Yargılama Usulüne Hâkim Olan İlkeler, Seçkin Yayın, Haziran, Ankara.

Yasin M. (2015). İdari Yargılama Usulünde İspat, Oniki Levha Yayınc1lık,1.Baskı, İstanbul.

Yavaşlar, F.B. (2012). Vergisel Düzenin ve Vergi Adaletinin Sağlanmasında Donanımlı Anayasa Dışında Gerekenler, Anayasadan Mali ve Vergisel Beklentiler Sempozyumu, Oniki Levha Yayıncılık,1. Baskı, İstanbul.

Yavaşlar, F.B. (2013). Vergi Ödevi İlişkisinin Tarafları Üzerinden Alman Vergilendirme Usulü, Seçkin Yayınları.

Yavaşlar, F.B. (2016). Vergilendirme Usulündeki Vergi Ödevleri ve Ödevlerin Yerine Getirilmemesinin Re'sen Araştırma İlkesi Karşısında Anlamı, Prof. Dr. İlhan Ulusan'a Armağan, İstanbul Kültür Üniversitesi Hukuk Fakültesi Dergisi, III. Cilt, Seçkin Yay., Ankara.

Yenice, K. \& Esin, Y. (1983). İdari Yargılama Usulü, Arıcan Matbaa, Ankara.

Zabunoğlu, Y. (1982). İdari Yargılama Usulü: Genel İlkeler Pozitif Düzenlemeler, İdari Yargıda Son Gelişmeler Sempozyumu, Ankara. 


\section{Extended Summary}

\section{The Limits of the Principle of Ex Officio Examination in the Turkish Tax Judiciary}

The constitutional basis of the tax jurisdiction law is based on the rule of law, which is Article 2 of the Constitution, and the judicial control of the administration in accordance with this principle. In accordance with Article 125 of the Constitution, the judicial review of the administration is carried out by the courts established in accordance with Article 142 of the Constitution, in tax jurisdiction, as in all jurisdictions.

In the resolution of tax disputes through judicial means; Tax Courts are the courts of first instance, the Regional Administrative Court of appeal and the Council of State are judicial bodies assigned for appeal purposes. In addition, the Council of State treats the cases written in the law as a first instance court. In the tax judgment law, the principles of the rule of law, legality of taxes, utility to the public, writing, ex officio research, freedom of evidence, free evaluation of evidence, economic approach, procedural economy and fair trial principles have been adopted.

One of these principles is "the principle of ex officio examination"; It refers to the judicial judge's ability to do research and investigation automatically in order to enlighten the dispute from the opening of the case to the final decision, regardless of the evidence put forward by the parties. The legal basis of this principle, it is based on the Constitution, laws and administrative regulations.

The main purposes of the principle of ex officio examination are; to realize the taxation in accordance with the constitution, democracy, social justice principle, equality principle and legality principle. Judges have been assigned broad powers and duties such as the right to examine, investigate, examine and examine both procedural and material issues in order to achieve these goals.

By the judicial organs, the means of proof of the dispute subject to the case must be submitted to the judicial authority by the parties of the case so that the trial can be conducted and concluded in a healthy manner. However, in this process, when deemed necessary, the judge can make use of the principle of ex officio examination in order to ensure the correctness of the judgment and the judgment to be established, as well as the information and documents presented by the parties. Even though judges are given broad powers and duties that will enable them to make correct, free and healthy decisions regarding the case they are facing, these powers are not unlimited within our legal system. It is observed that the principle of ex officio examination is limited with the provisions brought within the scope of the Constitution, Administrative Law of Procedure, Civil Procedure Law and Tax Procedure Law. In particular, the limits on the security or best interests of the state, the limits of the judge's non-arbitrariness, the limitations on the inability of tax courts to conduct an appropriateness control, the margin in terms of discretionary power and compliance with the law, the limits on proof and tax privacy, the limits established by the case law of the Council of State and the principle of ex officio examination. It covers issues such as being limited by other jurisdiction principles. These issues reveal the existence of the direct as well as indirect limits of the judge during the trial.

The duty of the tax jurisdiction, which is within the administrative jurisdiction and is important with its unique practices; to resolve disputes between the taxpayer and the tax administration. The superior position of the administration in both administrative and tax jurisdictions, the existence and importance of the public interest, the wealth of information, documents, other resources and opportunities that the administration has may reveal inequality between the parties. Thus, the necessity and importance of giving the judges the opportunity to 
act ex officio in an effective and free manner in order to ensure equality between the parties to the case and to conduct the proceedings accurately in the judicial process has emerged.

Judges in charge of judicial bodies contribute to bringing the revenues of taxes, duties, fees, etc., which are a public resource and receivable, to the state budget correctly and on time, and to provide public services in a timely manner. In addition, it will ensure that the taxpayer, who is usually on the other side of the case, is also dealing with the correct tax debt, and that the administration is not victimized and protected in terms of actions and transactions. While performing these duties, the tax judge has undertaken together with the parties to obtain the information, documents, etc. to enlighten the case and make the right decision. In fact, the judge usually uses the initiative on this subject, using his own initiative to conclude the case in a simpler and quicker way.

It is a positive approach that the principle of ex officio examination as an important principle in our tax jurisdiction law in terms of judicial technique and has been evaluated comprehensively. Successful implementation of this principle also contributes to the legality of taxes included in our Constitution and to ensuring justice in taxation. However, in the implementation of this principle, especially the judge does not act arbitrarily and goes beyond its purpose; it is of great importance in terms of the unique structure and technique of the tax jurisdiction that the regulations to be made to limit the request for information and documents are determined clearly, understandably and directly.

In this study, the definition and purposes of the principle of research and ex officio research are given, and the place and limits of this principle in tax jurisdiction are mentioned. In the Turkish Tax Judiciary, besides the broad powers and duties given to the judges with the principle of ex officio research, the indirect and direct boundaries of the principle are explained and literature and judicial decisions supported evaluations are also included in terms of the place and importance of the principle in the system and its contribution to the tax judiciary. 